Valentino Gasparini

\title{
Renewing the past: Rufinus' appropriation of the sacred site of Panóias (Vila Real, Portugal)
}

\begin{abstract}
The topic of "lived places" is here approached through the analysis of the rock sanctuary of Panóias (Assento de Valnogueiras, Vila Real de Trás-osMontes), one of the most popular archaeological sites in Portugal. When the Roman senator Gaius C(?) Calpurnius Rufinus, between the late 2nd and the mid-3rd century $\mathrm{CE}$, had to choose the most appropriate location for his intervention, he decided to build a shrine far away from an urban center, preferring Panóias' remote and numinous set of granite rocks, which had hosted cultic activities already in pre-Roman times. The senator, though promoting new ritual patterns linked with the cult of Isis and Serapis (namely the construction of, at least, a temple equipped with basins where sacrifices were performed), showed a strong interest in evoking the ancestry of the pre-existing religious practices and negotiating continuity with the new ones. The article explores the microstrategies enacted by Rufinus in order to introduce his innovation, elevate Serapis over all the other gods, paint the new cult with specific Eleusinian mystery traits, regulate the related liturgy, and thus significantly negotiate and renew a salient ancestral activity.
\end{abstract}

When dealing with the topic of "lived places", the issue raised by part of the subtitle of this section (viz. the individual appropriation of space) is absolutely crucial. This chapter focuses precisely on the topics of appropriation, bricolagist resacralization, and prolongation of memory through different media. My interest here lies in discussing micro-strategies for evoking the ancestry of local cultic practices, promoting new ritual patterns, negotiating continuity and change among

\footnotetext{
Acknowledgement: This paper has been conceived as part of the project The breath of gods. Embodiment, experience and communication in everyday Isiac cultic practice, in the context of Lived ancient religion. Questioning "cults" and "polis religion" (LAR), directed by Jörg Rüpke and funded by the European Union Seventh Framework Program (FP7/2013, $n^{\circ}$ 295555). Its final release has further benefitted from the involvement in the research group Historiografia $e$ Historia de las Religiones of the Julio Caro Baroja Institute of Historiography at the University Carlos III of Madrid, where Jaime Alvar Ezquerra leads a specific research project (2018-2021) on Epítetos divinos: experiencia religiosa y relaciones de poder en Hispania (EPIDI), funded by the Spanish Ministry of Economy and Finance (HAR2017-84789-C2-2-P).
}

Ә Open Access. () 2020 Valentino Gasparini, published by De Gruyter. (cc) BY-NC-ND This work is licensed under a Creative Commons Attribution-NonCommercial-NoDerivatives 4.0 International License.

https://doi.org/10.1515/9783110557596-017 
them, and manipulating pre-existing sets of religious options. By analyzing the rock sanctuary of Panóias and discussing the personal engagement by the author of a series of five inscriptions carved in its area, I will try to shed some light on specific processes involved in the dismantling and rebuilding of memory.

Panóias (Assento de Valnogueiras, Vila Real de Trás-os-Montes), which has been a Portugese National Monument since 1910 (Freitas et al. 2012-2013, 184 n. 1), is one of the most popular archaeological sites in Portugal. It lies at an altitude of $460 \mathrm{~m}$ above sea level in a mountainous region ( $85 \mathrm{~km}$ from the Atlantic coast) the characteristic feature of which are the ancient, smoothly-rounded granite outcrops (locally called "fragas") of the early Palaeozoic era.

The area now corresponding to Trás-os-Montes (north-eastern Portugal) has been more or less continuously inhabited since the Palaeolithic age. Prior to the Roman period, it was occupied by a people we know as the Lusitanians. It was nominally conquered by Decimus Iunius Brutus (later nicknamed "Callaicus" or "Gallaecus") in 137 BCE but the Roman occupation was consolidated only after Augustus' Cantabrian Wars (29-19 BCE). The area was incorporated into the conventus Bracaraugustanus (prov. Hispania Tarraconensis) and placed under the direct control of the municipium of Aquae Flaviae (Chaves) after the Flavian municipalization in $75 \mathrm{CE} .{ }^{1}$ Apart from the hot springs, Rome's interest in the area lay in the extraction of metals: the rich gold mines of Três Minas and Jales lie only $20 \mathrm{~km}$ north of Panóias. ${ }^{2}$

During Late Antiquity, Panóias was listed under its Latin name of Pannonias in the Parochiale Suevorum (569 CE) as the center of a parish belonging to the Suevian diocese of Braga. ${ }^{3}$ It is also attested as the site of a mint in the mid-Visigothic period, during the reigns of Witteric (603-610 CE) and Sisebut (612-621 CE). ${ }^{4}$

\section{$1 \mathrm{~A}$ brief history of exploration at the site}

In 1721, the King of Portugal, João V, ordered the Senate of Vila Real to send the Royal Academy of History in Lisbon a detailed report assembling the main

\footnotetext{
1 Cf. CIL II 2477 = 5616 (with Hübner's commentary) = Rodríguez Colmenero 1997, 418-426, n $^{\circ}$ 587.

2 Domergue 1990, 201; Tranoy 2004, 88; Martins 2010; Fonseca Sorribas 2012, 525.

3 I 1, 19. The codex "G" already testifies the variant Panoias. Cf. Rodríguez Colmenero 1999, 24 n. 27.

4 Russell Cortez 1947, 66-73; Rodríguez Colmenero 1999, 19 n. 1 and 23-25.
} 
information concerning the local remains of historical note. This report survives under the name Relação da Câmara. A similar request was sent by the Academy to the local parish priests. Of these, António Rodrigues de Aguiar, priest of the church of S. Pedro de Valnogueiras at Panóias, provided a document entitled Relação da Fr(e)guesia de S(ao) Pedro de Valnogueiras Con(cell) de Villa Real Arzebispado de Bragas Primaz das Hespanhas, containing eight drawings and twenty pages of text. ${ }^{5}$ Some years later, in 1732, both reports were read by Jerónimo Contador de Argote, a member of the Academy. Although he never visited the site personally, he published excerpts from these documents, describing some of the carved and inscribed rocks and illustrating eleven of them in his plates. Unfortunately, these illustrations were very inaccurate neo-Classicist redrawings by Gabriel François Louis Debrie of the images already made for the Relação da Câmara (Contador de Argote 1732, I, 325-359).

Both Contador de Argote and, more than a century later, William Henry Giles Kingston attest to the former presence of numerous marble columns, capitals, and slabs at the site, most of which had already been moved to Vila Real as construction materials or re-used in the local church of S. Pedro. ${ }^{6}$ Apart from Kingston, we know of a few other travellers who visited and documented the ruins of Panóias during the 19th century, notably Alexandre Herculano and Gabriel Pereira (Herculano 1839a; 1839b; Pereira 1895). But by far the most important visitor came towards the end of the century (1888). Jose Leite de Vasconcellos, the pioneer of Portuguese archaeology and later founder of the National Museum of Archaeology in Lisbon, devoted several pages of his wide-ranging work to Panóias, incorporating material collected in an earlier report (Apontamentos sobre monumentos antigos existentes em Panóias) written in 1883 by João Henrique von Hafe, an engineer under contract to the Portuguese railways. ${ }^{7}$

It is only since the cleaning of the site in 1942 and the topographical survey of 1951 that Panóias has once again begun to attract the attention of historians, so that the relevant bibliography is now quite considerable. ${ }^{8}$ The land itself has

5 Bibl. Nac. Lisboa, inv. n 222. Cf. Russell Cortez 1947, 20 n. 1; Rodríguez Colmenero 1999, 19, 29-31, 143-195 and 197-219; Alvar 2012, 139-140; Abreu 2016, 14-15.

6 Contador de Argote 1732, I, 326; Kingston 1845, II, 351. Cf. also Lambrino 1954, 117 and Rodríguez Colmenero 1999, 221-229. See in particular Kingston 1845, II, 351: "The last tower (sic) was a short time ago destroyed to construct a belfry for the church, and the padre had placed a Corinthian capital on one side of the top of it."

7 Vasconcellos 1895a; 1895b; 1897a; 1897b; 1897-1913, II, 187-188; III, 81, 301, 345-347, 465-474 (with indices and commentaries collected in Bárcia 1982 and Garcia 1991).

8 Cardoso 1943; Russell Cortez 1947; Lambrino 1954; Alföldy 1995; 1997; Azevedo 1998; Rodríguez Colmenero 1999; Alföldy 2002; Tranoy 2004; Alvar 2012, 138-146; Freitas et al. 
recently been acquired by the state (1993), fenced (1995), freed of some modern buildings, and equipped with a ticket office, a bookshop, and a small auditorium (2004) (Freitas et al. 2012-2013, 184-186; Abreu 2016, 16). Unfortunately, however, no proper archaeological excavation using modern techniques has yet been conducted at the site.

\section{The archaeological remains}

The Roman occupation of the site is demonstrated beyond doubt by the marble architectural elements mentioned by Contador de Argote and Kingston, ${ }^{9}$ as well as by the discovery in the area of several Imperial coins. Kingston says that he was presented by the local priest with a coin showing a gladiator on one face and the head of an Emperor on the other (Kingston 1845, II, 351). What still survives of the Roman presence is a series of basins and cavities of different shapes and dimensions directly hewn out of the granite outcrops (Fig. 1). These features are mainly concentrated on as many as ten rocks of very different size and include 1) small shallow circular hand-excavated cavities, for which I here adopt the French term "cupules"; 2) square or rectangular tanks or small cisterns; 3) various channels; and 4) flights of steps, which are probably part of a zigzag path leading across the rocks (Fig. 2). ${ }^{10}$

The surviving features on Rock III (Fig. 3) have made it clear that no less than three different phases of use must be distinguished. The earliest is characterized by the cutting of "cupules" connected by channels. To this phase belongs an incised frame bearing non-recoverable signs (probably geometric symbols). The second phase saw the cutting of an access-staircase and five tanks with bevelled edges that seem to have been furnished with lids or covers. During the third phase, a rectangular hall $(4 \times 4.50 \mathrm{~m})$ was built directly onto the rock and held in place by rectangular dowels fitted into the stone (these slots are in fact the only surviving evidence of the existence of the building) and incorporating two of the basins from the first phase (Alföldy 1997, 220-223; Rodríguez Colmenero 1999, 48-57).

2012-2013; Sousa and Silva 2013; Sousa Santos, Pires and Sousa 2014; Pires et al. 2014; Abreu 2016; Redentor 2016; Schattner 2017, 363-365 and 376-377.

9 Some granite architectural elements are still visible, reused in the walls of the local modern buildings: cf. Rodríguez Colmenero 1999, 23 and 24, fig. 5.

10 The following brief description requires the reader to move repeatedly between the text and the related figures. 


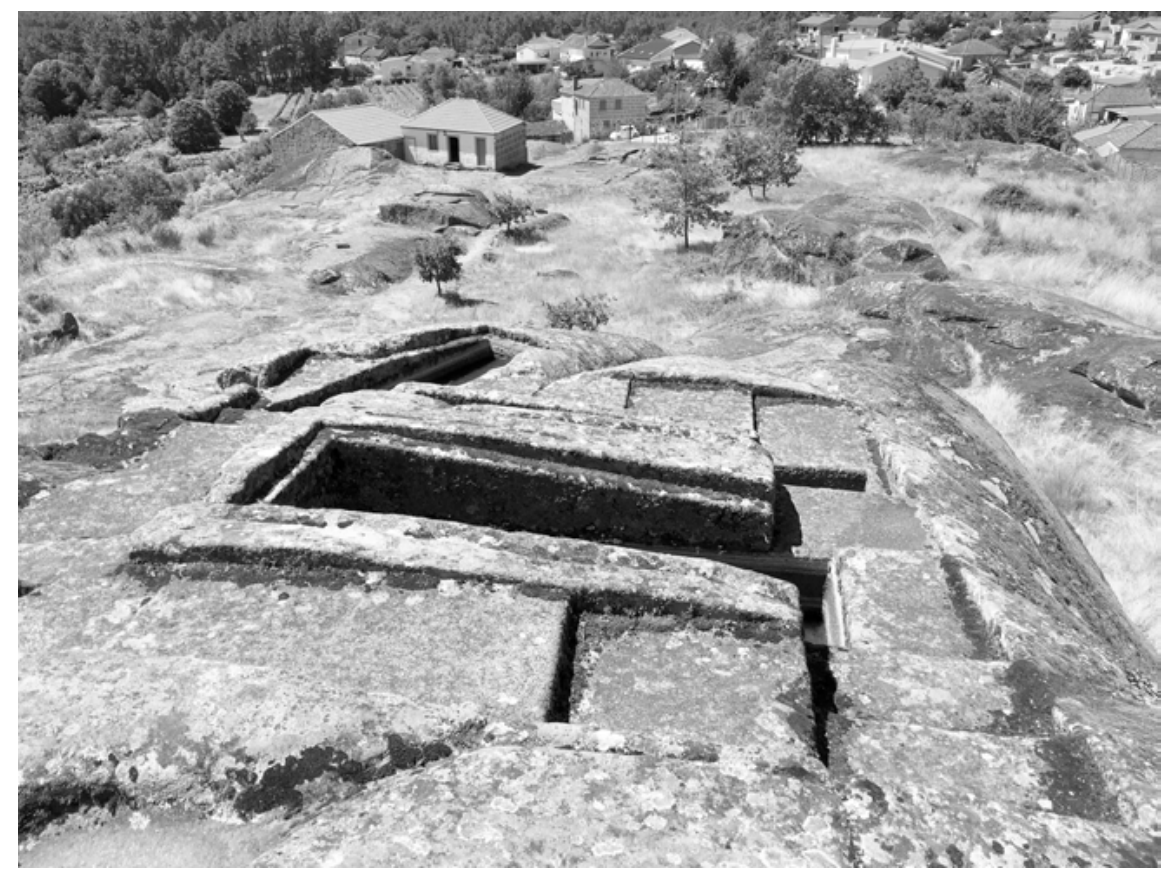

Fig. 1: The site of Panóias (photo V. Gasparini).

Another outcrop (also carved with a series of "cupules" linked by channels, then probably replaced or implemented by a small rectangular basin with bevelled edges, originally covered by a metal grid) led to the second monumental complex of Rock II (Fig. 4). Here again it has proved possible to detect three phases of construction or use: a first phase that is again characterized by small circular cavities (connected by a channel); a second phase with tanks with bevelled edges; and finally a third phase, with a monumental building (4.2 x $3.3 \mathrm{~m}$ ) served by a staircase, a door, and three apparently anepigraphic frames (although we cannot exclude the possibility that texts were painted on these rather than inscribed). This building again incorporated two deep basins from an earlier phase (Alföldy 1997, 215-219; Rodríguez Colmenero 1999, 58-65).

Finally, Rock Ia (Fig. 5) presents an irregular horizontal terrace on which a third monumental building ( 5 x $4.5 \mathrm{~m}$ ) was built, lying directly on the rock and stabilized by dowels. Inside it were five square or rectangular bevelled basins (0.60-0.68 m deep) with small notches for covers; a sixth tank is circular. Facing the building (at the side of a modern house, the construction of which probably destroyed other ancient remains), at least two altars were built on top 


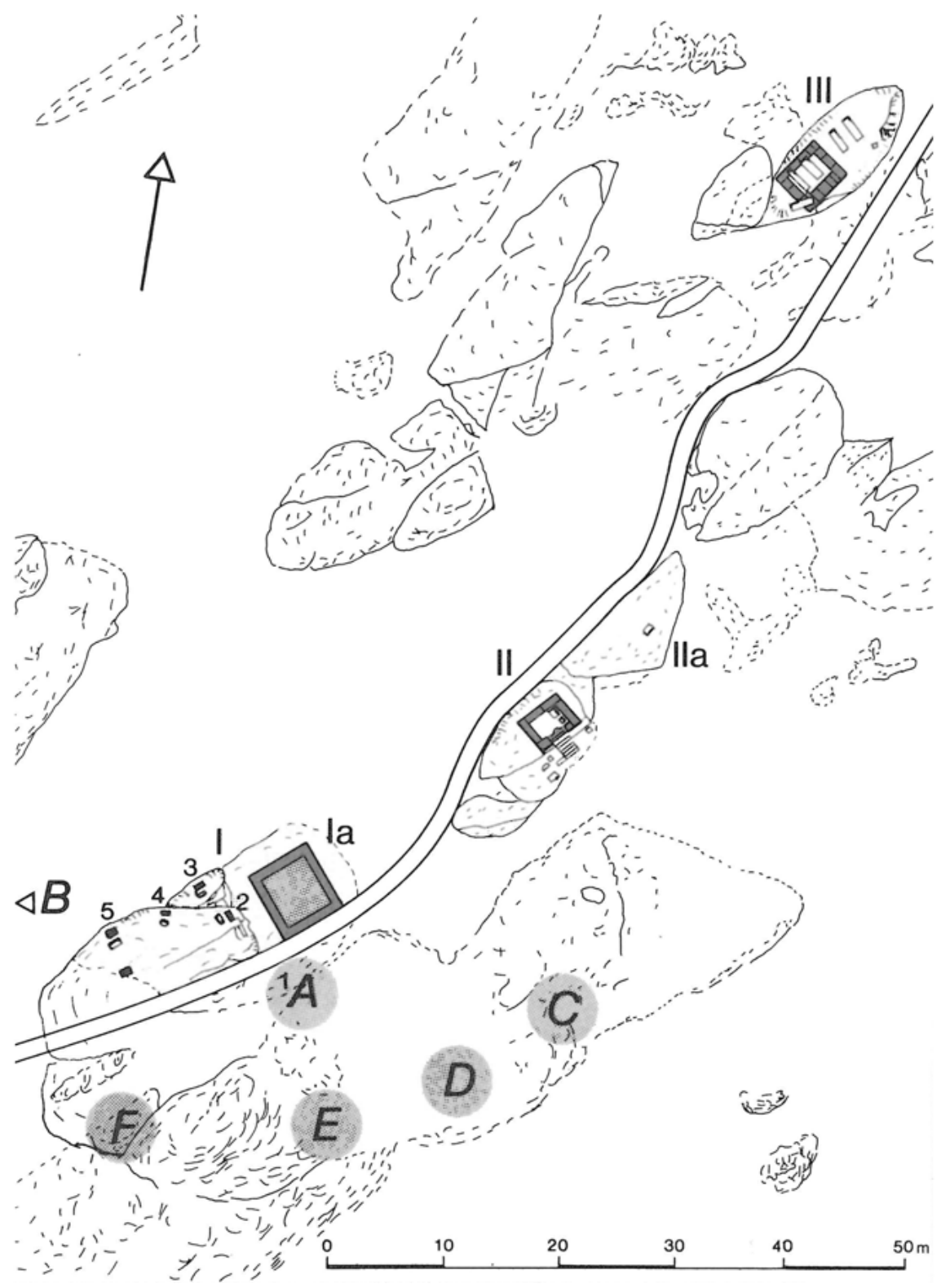

Fig. 2: Plan of the sanctuary of Panóias (after Alföldy 1997, 177, fig. 1). 


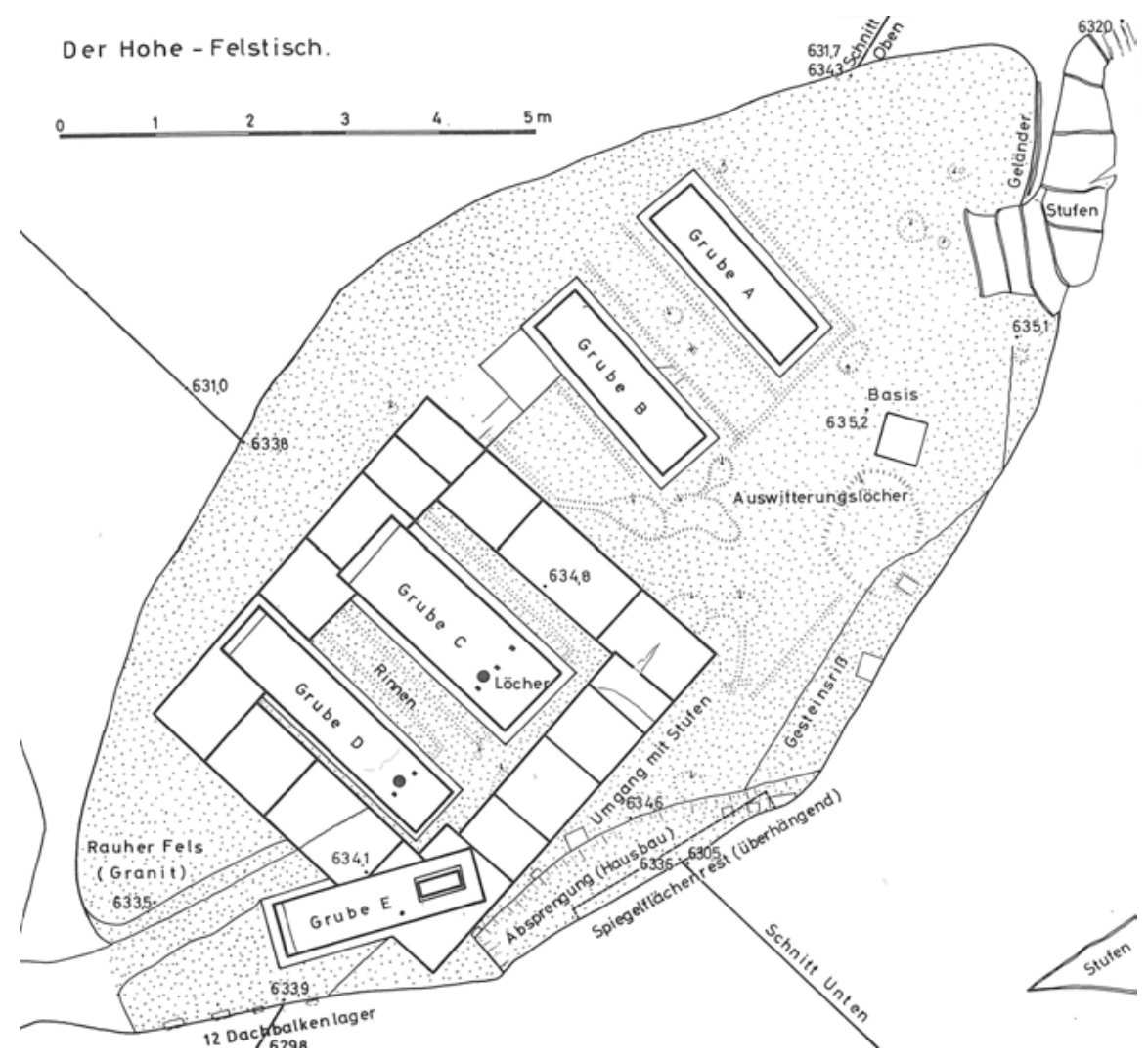

Fig. 3: Plan of the higher temple (III) (after Alföldy 1997, 220, fig. 11).

of rocks, with further traces of two staircases (one of them miniature) and small channels. Along the southern side of the ancient building was a further complex (Rocks I), in this case with three rectangular tanks and a circular one (all measuring 0.34-0.49 m deep). All four have bevelled edges, notches for metal lids or grids, and inscriptions (see below) (Alföldy 1997, 209-213; Rodríguez Colmenero 1999, 65-71).

These remains have, of course, inspired countless flights of fantasy. Many of these, including Francisco Fernandes Pereira's suggestion that the tanks were meant for storing precious minerals, can be dismissed out of hand. Pereira's hypothesis was clearly influenced by Roman mining activity in the region, which even prompted him to invent a pseudo-etymology of the name Panóias, which he derived from Penas Auri, i.e. "Golden Rocks" (Pereira 1836. Cf. Rodríguez Colmenero 1999, 19 n. 1, where he is cited under the erroneous name of 


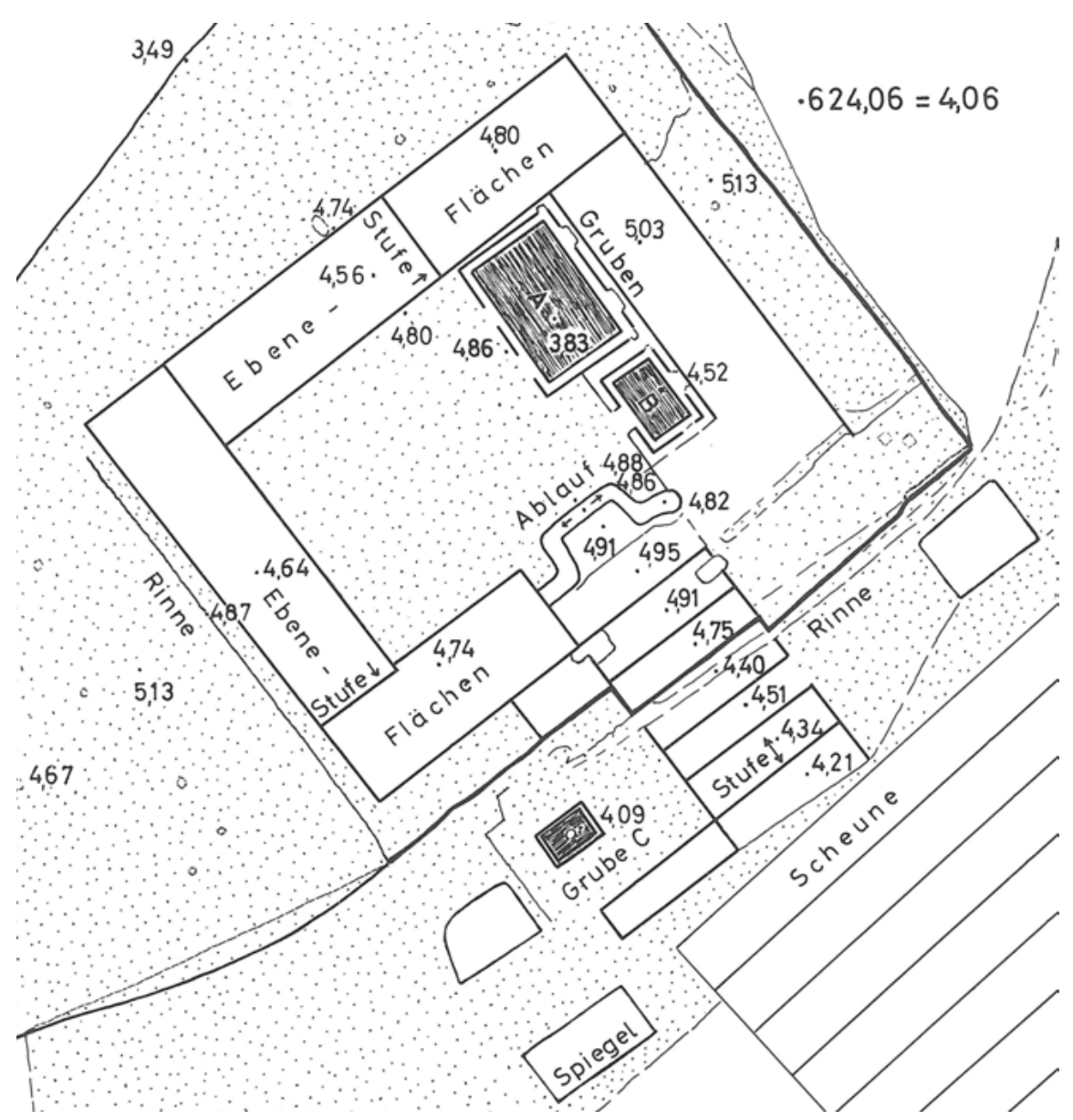

Fig. 4: Plan of the middle temple (II) (after Alföldy 1997, 218, fig. 9).

Ferreira). The priest who guided Kingston during his visit in 1845 referred to the discovery of skeletons in at least some of the basins, which of course suggested that the site was a sort of necropolis. ${ }^{11}$ It is, however, certain that there was a Roman necropolis (and consequently a village or, at least, a villa) nearby, as is attested both by Rodrigues de Aguiar's Relaçã $0^{12}$ and by the discovery of as

11 Kingston 1845, II, 350-351. Cf. Lambrino 1954, 107; Rodríguez Colmenero 1999, 21.

12 Apud Rodríguez Colmenero 1999, 19: achãose tambem sepulturas antigas em pedras com modo de cabeça e hombros como em muitas partes hai. 


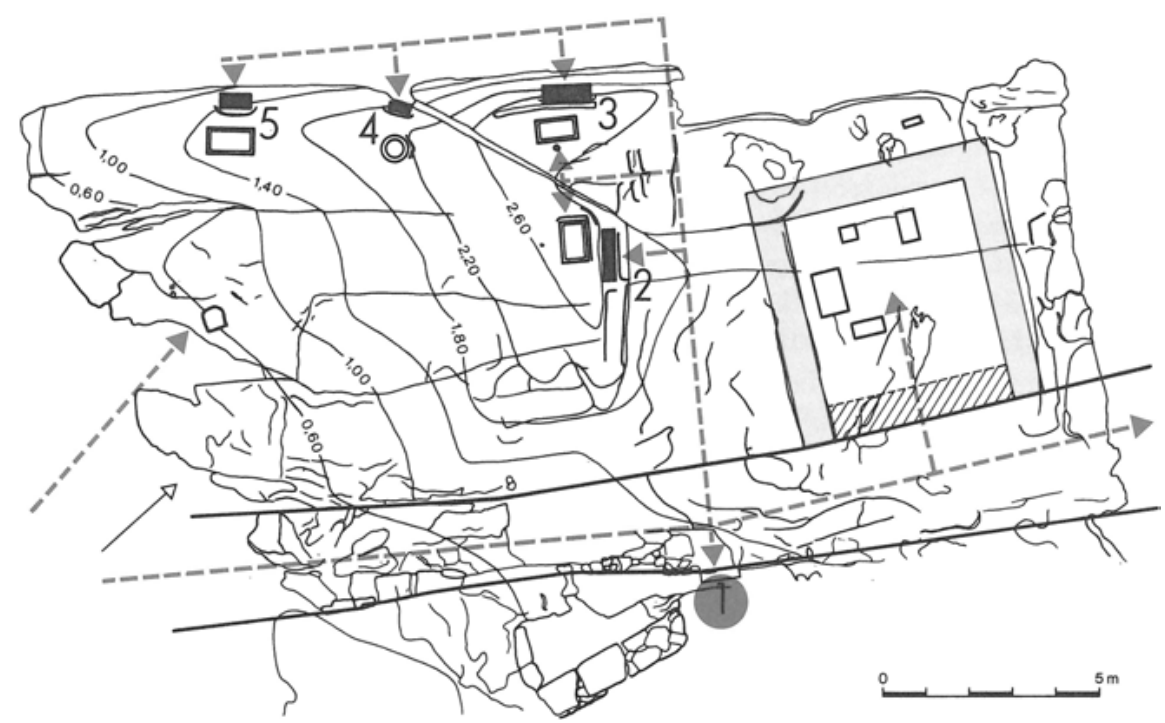

Fig. 5: Plans of the lower temple (la) with location of the inscriptions CIL II 2395a-d (after Alföldy 1997, 199, fig. 7).

many as six funerary granite steles inscribed in Latin and dating to the 2nd or 3rd century CE. ${ }^{13}$ Given this, we cannot, of course, exclude the possibility of lateantique or medieval re-use of the Roman cavities as tombs. ${ }^{14}$

13 1) [D(iis)] M(anibus) s(acrum) / [F]lavio / Albino / Maxu/mina / [u]xor pi/[is]sima / [f(aciendum)] c(uravit). Cf. CIL II suppl. 5553; Cardoso 1943, 92; Russell Cortez 1947, 25; Rodríguez Colmenero 1997, 261-262, $\mathrm{n}^{\circ}$ 284; Rodríguez Colmenero 1999, 22. The deceased is probably the same person who had offered a dedication to the Lares Viales at Bracara Augusta, $70 \mathrm{~km}$ north-west of Panóias: Larib(us) Viali/bus $<F=I>l($ avius) A[l]/binus v(otum) / s(olvit) l(ibens) $m$ (erito). Cf. CIL II 2417.

2) Trites M/ebdii (filius) h(ic) s(itus) / est. Taur/ocutius / Apoltae / f(ilius) f(aciendum) c(uravit) / d(e) s(ua) p(ecunia). / Aucalus / Hospites / Arcius et / Urtinus / p(osuerunt). Cf. CIL II suppl. 5556; Cardoso 1943, 95; Russell Cortez 1947, 25; Rodríguez Colmenero 1999, 22-23.

3) $[-]$ RI / [-]ONI / [-]S[-]. Cf. Rodríguez Colmenero 1997, 294, nº 370; Rodríguez Colmenero 1999, 22.

4) Aureolae. Cf. CIL II 2396a; Russell Cortez 1947, 26; Rodríguez Colmenero 1999, 21.

5) Modestia. Cf. CIL II 2396b; Russell Cortez 1947, 27.

6) Millia stipib(us). Cf. CIL II 2396c; Russell Cortez 1947, 27; Rodríguez Colmenero 1999, 21. 14 Such reuse may have happened at the similar rock sanctuary of Pias dos Mouros (Argeriz, Valpaços), 40 km north of Panóias. Cf. Santos 2010a, 193-195; 2010b, 149-151. 


\section{The inscriptions}

The crucial information regarding the site of Panóias is provided not by the rock-cut features, but by the epigraphy. As noted above, Rock I has four small basins, each of which carries an inscription. A fifth, which was recorded by Contador de Argote and von Hafe, but destroyed between 1883 and 1888, was located somewhere in the vicinity. The fact that all are seriously eroded has provoked numerous different readings over the last three centuries. ${ }^{15}$ Fortunately for my purposes, they have recently been analyzed by means of a new algorithm, the "Morphological Residual Model" (MRM) (Santos, Pires and Sousa 2014; Pires et al. 2014), which has greatly improved their legibility. In addition to showing that there are one or two probable misunderstandings by the authors of this last analysis (which have required further small modifications: see below), it is possible now to offer new, relatively reliable readings of the inscriptions:

1) Diis [-] / huius hostiae quae ca/dunt hic immolantur, / exta intra quadrata / contra cremantur, / sanguis laciculis iuxta / superfu[ndi]tur. ${ }^{16}$ Now lost.

To the gods ( - and - ), of which the sacrificed victims are immolated here, (their) internal organs are burnt into the square basins in the front, (their) blood is poured over the smaller basins next to them.

2) Diis Serapidi Isidi, / diis deabus omni/bus lacum et [hanc?] / aedem G(aius) $[C(-) C]$ alp (urnius) Ru/ $/ 5$ finus v(ir) $c$ (larissimus) (Fig. 6). ${ }^{17}$ In situ.

Gaius C. Calpurnius Rufinus, vir clarissimus, (dedicated) the basin and (this?) temple to the gods Serapis (and) Isis, (and) to all the gods (and) goddesses.

15 According to Tranoy 2004, 92-93, it is possible that the inscriptions were re-inscribed in modern times (17th-18th century), because of their very poor degree of conservation.

16 CIL II 2395e = Eph.Epigr. IX 1913, p. 98. Cf. Contador de Argote 1732, I, 343; Vasconcellos 1897b and 1897-1913, III, 469; Russell Cortez 1947, 60-63; Lambrino 1954, 114-115, n 5; García y Bellido 1956, 49-52; Rodríguez Colmenero 1993, 62-63, n 29; Rodríguez Colmenero 1995, 174-175, n 29; Alföldy 1997, 184-189; Búa Carballo 1999, 310; Rodríguez Colmenero 1997, 178-179, n 162; Rodríguez Colmenero 1999, 81-84; Alvar 2012, 140-141, nº 193; Santos, Pires and Sousa 2014, 204-205; Redentor 2016, 207.

17 CIL II 2395a. Cf. Contador de Argote 1732, I, 341-342; Kingston 1845, II, 350; Russell Cortez 1947, 64; Lambrino 1954, 111-113, n 4; García y Bellido 1956, 47-48; Rodríguez Colmenero 1993, 69-70, n 33; Rodríguez Colmenero 1995, 182-186, nº 33; Alföldy 1997, 189-192; Búa Carballo 1999, 310; Rodríguez Colmenero 1997, 116, nº 86; Rodríguez Colmenero 1999, 84-85; Alvar 2012, 141-142, n 194; Santos, Pires and Sousa 2014, 205-210; Redentor 2016, 205. 

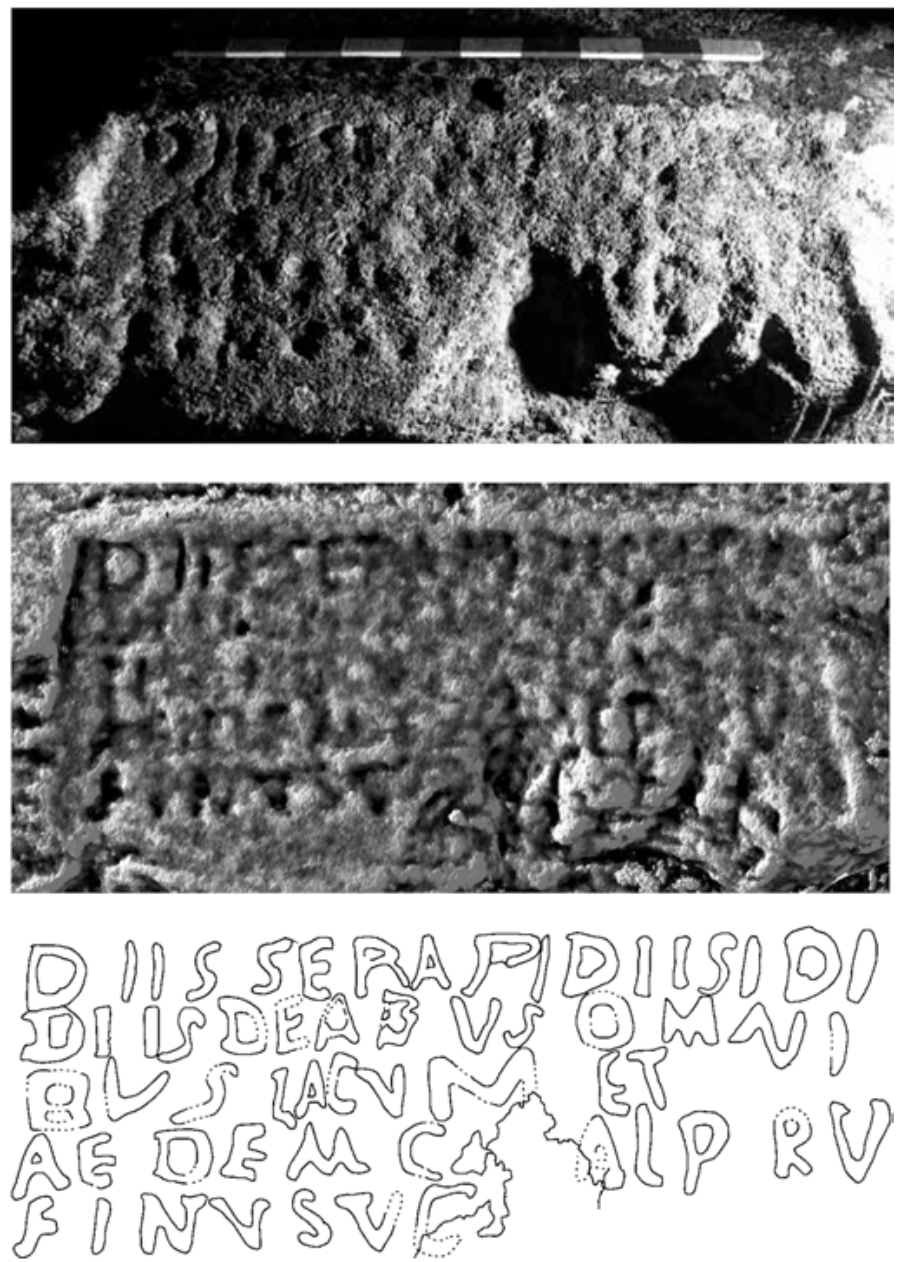

Fig. 6: Photograph, MRM model, and transcription of CIL II 2395a (after Santos, Pires and Sousa 2014, 206-208, figs. 3, 5 and 7).

3) Diis deabusque ae/ternum lacum omni/busque numinibus / et Lapitearum cum / hoc templo sacravit / G(aius) C(-) Calp(urnius) Rufinus v(ir) c(larissimus) / in quo hostiae voto / cremantur (Fig. 7). ${ }^{18}$ In situ.

18 CIL II 2395b. Cf. Contador de Argote 1732, I, 345-346; Vasconcellos 1897-1913, III, 468; Russell Cortez 1947, 8 and 59-60; Lambrino 1954, 108-109, n 1; García y Bellido 1956, 44-46; Gil Fernández 1985, 367-369; Rodríguez Colmenero 1993, 63-65, n 30, Rodríguez Colmenero 1995, 176-177, nº 30; Alföldy 1997, 192-194; Búa Carballo 1999, 310; Rodríguez 

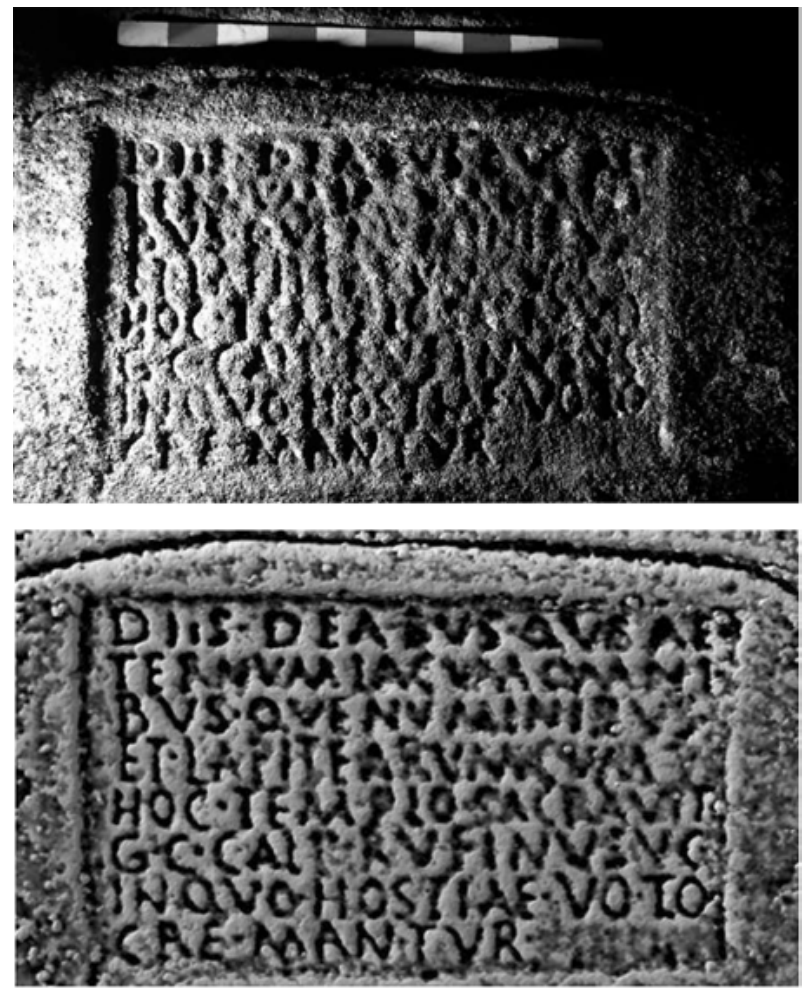

\section{$D \| S \cdot D E A B \vee S Q V E A E$ TERNVMLACVMOMNI BVS.QVENVMINIBVS. ET.LAPITEARVMCVM HOC.TEMPLO.SACRAVIT G.C.CALP.R VFINVS.V.C. INQQVO.HOSTIAE.VOTO CREMANTVR}

Fig. 7: Photograph, MRM model, and transcription of CIL II 2395b (after Santos, Pires and Sousa 2014, 211-212, figs. 9 and 11; Alföldy 1997, 193, Abb. 4).

Colmenero 1997, 179-180, n 163; Rodríguez Colmenero 1999, 85-88; Guerra 2002; Alvar 2012, 142-143, n 195; Santos, Pires and Sousa 2014, 210-212; Redentor 2016, 205. 
Gaius C. Calpurnius Rufinus, vir clarissimus, consecrated to the gods and the goddesses (this) eternal basin, where the victims are burnt according to a vow, together with this temple (dedicated) to all the deities, including those of the Lapiteae.

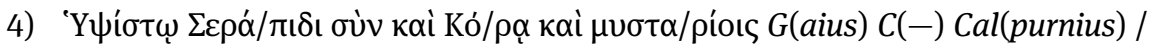
Rufinus v(ir) c(larissimus) (Fig. 8). ${ }^{19}$ In situ.

Gaius C. Calpurnius Rufinus, vir clarissimus, (dedicated this) to Serapis the Highest, together with Korê and the mysteries (?).

5) Diis cum aede / et lacum qui / voto misce/tur / G(aius) C(-) Calp(urnius) Rufi/nus v(ir) c(larissimus) (Fig. 9). ${ }^{20}$ In situ.

Gaius C. Calpurnius Rufinus, vir clarissimus, (dedicated) to the gods also the basin, which is joined to the temple according to a vow.

These texts call for a brief commentary before I proceed to integrate them into an interpretation of the complex as a whole. I thus discuss in turn the deities, the use of the rock-cut features, and the donor.

\subsection{The deities}

It is obviously impossible to test the (lost) inscription $\mathrm{n}^{\circ} 1$ by means of MRM, therefore we cannot tell what followed the allusion to Diis read by von Hafe. ${ }^{21}$ In the (fully preserved) inscription $n^{\circ} 5$, Diis is intentionally vague but the

19 CIL II 2395c = AE 1897, 86 = Eph.Epigr. IX 1913, p. $98=$ SEG XLVI (1996) $1373=$ SIRIS $758=$ RICIS 602/0501. Cf. Contador de Argote 1732, I, 346; Vasconcellos 1897a, 59-60 and 1897-1913, III, 345-347; Russell Cortez 1947, 57-59; Lambrino 1954, 109-110, nº 2; García y Bellido 1956, 42-43; 1967, 133-134; Alföldy 1995, 256; Rodríguez Colmenero 1993, 65-67, n 31; Rodríguez Colmenero 1995, 177-180, n 31; Alföldy 1997, 194-196; Búa Carballo 1999, 311; Rodríguez Colmenero 1997, 118-119, n 89; De Hoz 1997, 85-86; Rodríguez Colmenero 1999, 88-90; Dias, Gaspar and Mota 2001, 18-19, nº 2; De Hoz 2011, 81-82; Alvar 2012, 143-144, n 196; De Hoz 2013, 220-222; Santos, Pires and Sousa 2014, 213-218; De Hoz 2014, 465-467, nº 429; Redentor 2016, 206.

20 CIL II 2395d. Cf. Contador de Argote 1732, I, 346; Russell Cortez 1947, 63; Lambrino 1954, 110-111, no 3; García y Bellido 1956, 46-47; Rodríguez Colmenero 1993, 67-69, n 32, Rodríguez Colmenero 1995, 180-182, nº 32; Alföldy 1997, 196-198; Búa Carballo 1999, 311; Rodríguez Colmenero 1997, 180-181, n 164; 1999, 90-93; Alvar 2012, 144-145, n 197; Santos, Pires and Sousa 2014, 219-221; Redentor 2016, 206.

21 Diis [omnipotentibus] Lambrino 1954, 115; Diis [loci] Rodríguez Colmenero 1993, 63; 1999, 81; Diis [loci huius] Rodríguez Colmenero 1995, 175; 1997, 179; Diis [deabusque templi] Alföldy 1997, 187; Búa Carballo 1999, 310; Alvar 2012, 140; Santos, Pires and Sousa 2014, 204; Redentor 2016, 207. 

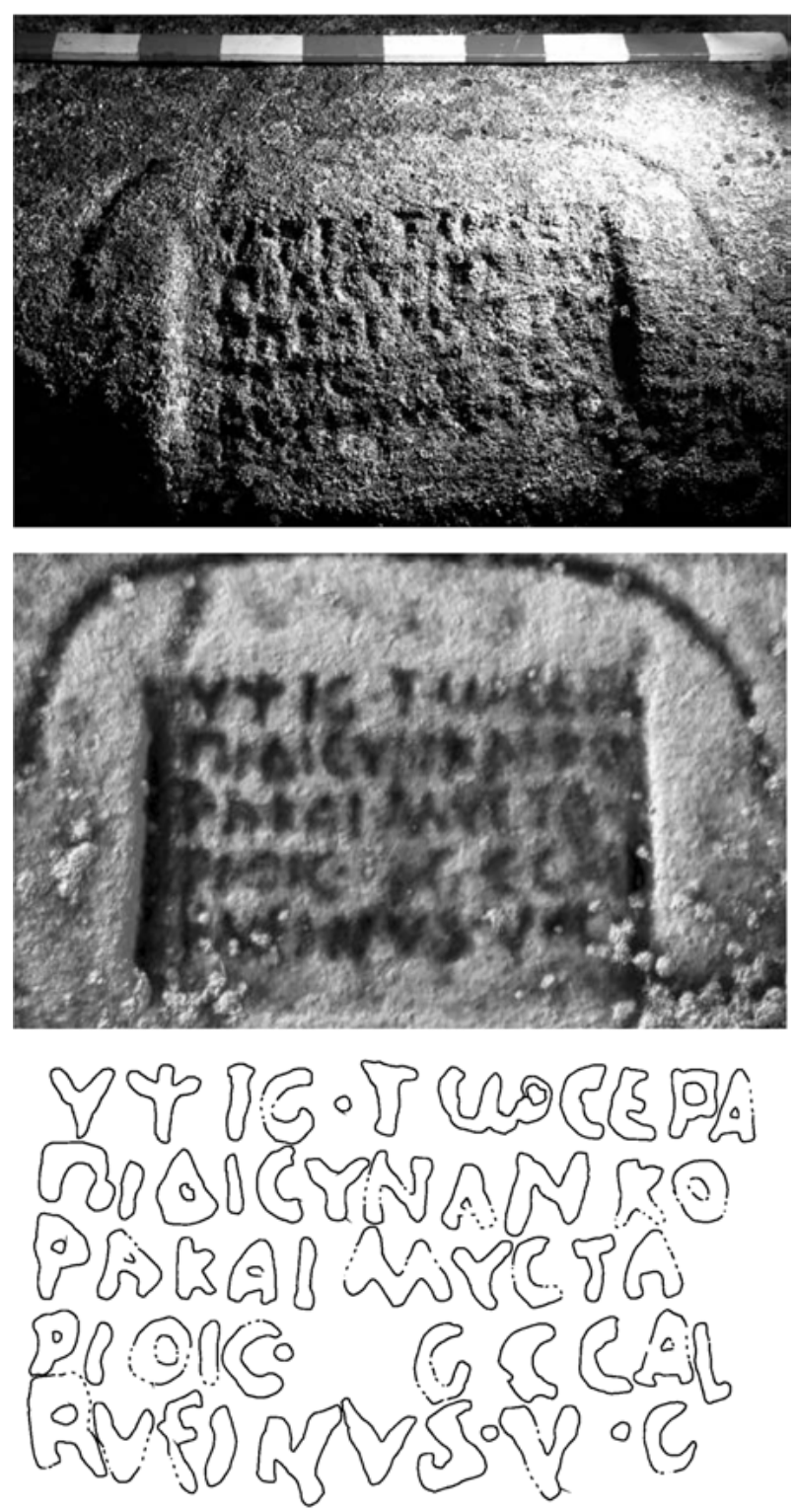

Fig. 8: Photograph, MRM model, and transcription of CIL II 2395C (after Santos, Pires and Sousa 2014, 216-218, figs. 13, 15 and 17). 

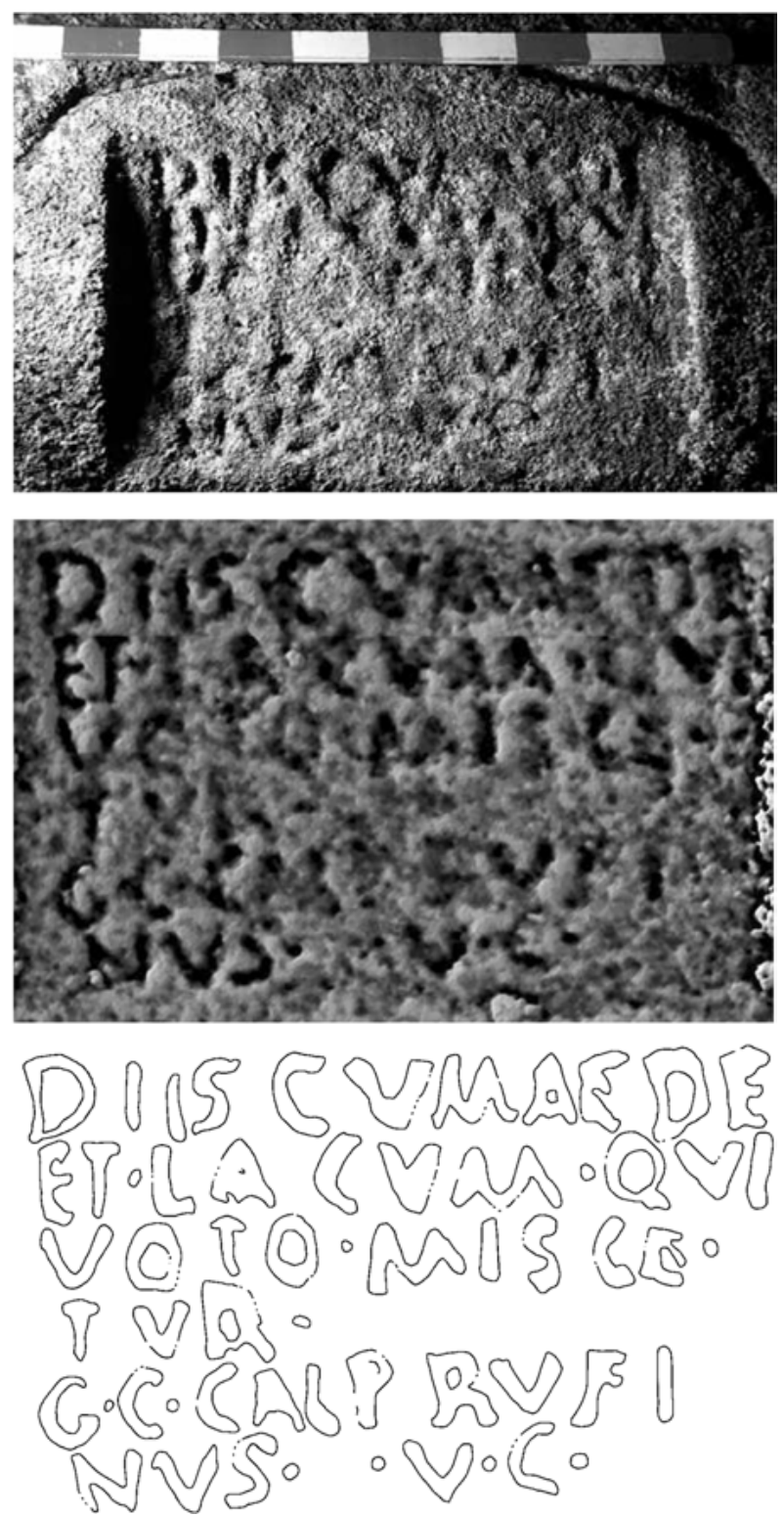

Fig. 9: Photograph, MRM model, and transcription of CIL II 2395d (after Santos, Pires and Sousa 2014, 220-222, figs. 19, 21 and 23). 
following presence in no. 1 of the genitive singular pronoun huius suggests that a singular theonym had to be placed before it.

Inscription no. 2 is fortunately richer in details. For a long time, the text has been read as a (problematic) mention to the Dii Severi, ${ }^{22}$ which were identified by Contador de Argote (1732, I, 353) as some infernal gods, namely Serapis and Isis invoked under the prerogatives of Pluto (Dīs) and Proserpina (Korê), Lord and Lady of the Underworld (cf. Lambrino 1954, 122-123; Tranoy 2004, 94). The new MRM reading has provided us with a much more plausible solution (Diis Serapidi Isidi, diis deabus omnibus), which has, moreover, the merit of explicitly reintegrating the goddess Isis at her paredros' side.

Inscription no. 3, whose reading is more or less secure, is dedicated Diis deabusque omnibusque numinibus et Lapitearum. Whereas the first formula was quite popular during the 3rd century CE (Tranoy 2004, 90), the reading of numina Lapitearum (almost universally accepted) ${ }^{23}$ has caused much discussion. Despite Amílcar Guerra's attempt at identifying these deities (the name of whom would derive from the Latin lapis) with some "oriental" or "mystery" cult (Guerra 2002, 158), it is much more plausible to consider them as local, pre-Roman gods. It has been suggested that they might be water-deities linked to the Cape d'Ortogal

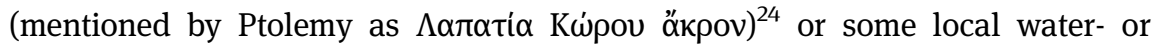
mother-deities called Lapiteae (Lambrino 1954, 121; Blázquez Martínez 1962, 184), or as the numina of a local population, ${ }^{25}$ or again the numina of a local toponym (Lapitea $-<{ }^{\star}$ Lapitia), hinting at the presence of crags. ${ }^{26}$

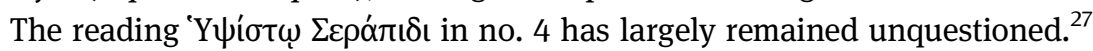
But MRM analysis has shown that the text does not mention Moipa (Moira) or

22 Diis Sev(eris) Man(ibus) Diis Ira/tis Rodríguez Colmenero 1993, 70; Diis Se(veris) M-a-n(ibus) Diis Ira(tis) Rodríguez Colmenero 1995, 185; 1997, 116; 1999, 84; Diis Deabusque [loca]/tis Rodríguez Colmenero 1997, 116; Diis [Deabusque hic loca]/tis Rodríguez Colmenero 1999, 84; Diis Seve(r)is in hoc / templo lo(ca)t(i)s Alföldy 1997, 191; Búa Carballo 1999, 310; Alvar 2012, 141; Diis Sev[eris locatis] in hoc / templo [-] Lambrino 1954, 113.

23 But see for Lapitearum L. 4, amphitheatrum Mommsen (CIL); (ex) lapide aram Gil Fernández 1985, 368; Tranoy 2004, 93.

24 Ptol. II 6, 4. Cf. Vasconcellos 1897-1913, II, 187-188.

25 Contador de Argote 1732, I, 345; Vasconcellos 1897-1913, III, 468, n. 1; Russel Cortez 1947, 9 and 60; Alvar 2012, 143.

26 *lapa- / *lapi-, "rock", > *lapa-to / *lapi-to, "rocky", > *Lapat-ia / Lapit-eae, "rocky place". Cf. Búa Carballo 1999, 311-312. And see also Vasconcellos, 1897-1913, III, 468; Russell Cortez 1947, 9.

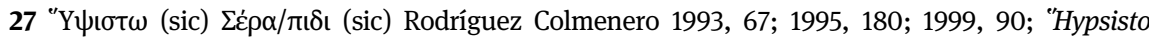

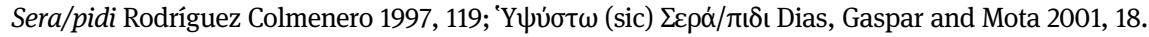




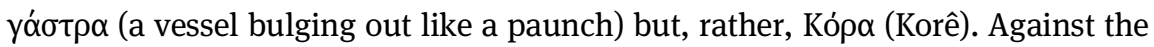

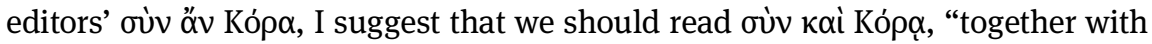
Korê". ${ }^{28}$ The dedication is completed by the mention of the mysteries, ${ }^{29}$ which fits with the Eleusinian allusion inherent in Korê, although I find it difficult to take it as the addressee of a dedication. I am, therefore, tempted to think that

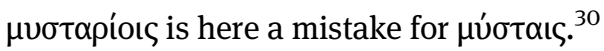

All these texts come from a single outcrop and we have no means now of knowing whether other deities were invoked elsewhere on the site. After all, Kingston claimed that there were inscriptions on the majority of the rocks and it is still possible to detect at least six frames which might originally have carried text, as at the entrance of the sanctuary at Rock II, for example. ${ }^{31}$ The original presence of further inscriptions hinting at local pre-Roman deities is suggested by Rodríguez Colmenero's identification of a sixth rock inscription found in the center of the modern local village of Assento (60 m from the sanctuary) and supposedly mentioning the god Vurebo. ${ }^{32}$

It is thus misguided to label the complex a Serapeum without qualification (as do, for example, García y Bellido 1967, 134). The site clearly reveals the cohabitation of the Isiac deities with a number of other numina. ${ }^{33}$

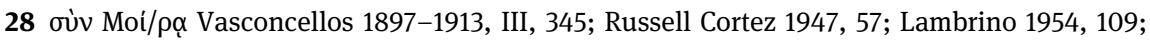

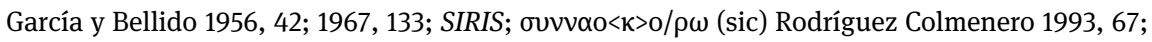

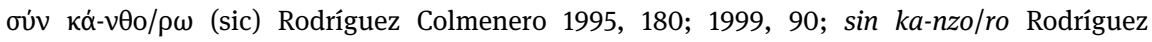

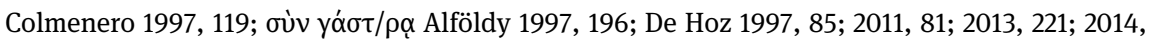
466; Dias, Gaspar and Mota 2001, 18; Alvar 2012, 143; oùv ővv Kópa Santos, Pires and Sousa 2014, 213.

29 kai misto/riois (templum sacravit) Rodríguez Colmenero 1997, 119; Naí Russell Cortez 1947,

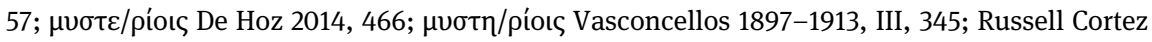

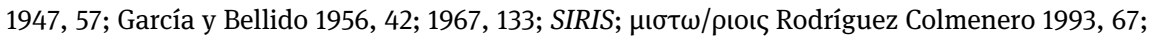

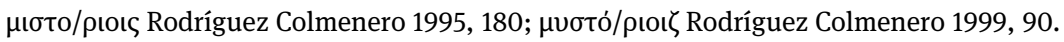

30 I thank Marco Galli for suggesting to me this possibility.

31 Kingston 1845, II, 350; Russell Cortez 1947, fig. 14; Lambrino 1954, 115; Rodríguez Colmenero 1999, 93.

32 Rodríguez Colmenero 1993, 73-74, n 37; 1995, 187-190, n 37; 1999, 94: Vur/ebo / T(itus) S(ulpicius) pos(uit). Other presumed inscriptions are recorded by the author in Rodríguez Colmenero 1993, 70-73, $\mathrm{nn}^{\circ}$ 34-36; 1995, 186-187 nn ${ }^{\circ} 34-36$. Cf. RICIS *602/0502 and Bricault 2008, 99.

33 Vasconcellos 1897-1913, 345 and 474; García y Bellido 1956, 52-53; Wild 1984, 1831-1832; Alföldy 1997, 231; Rodríguez Colmenero 1999, 105. 


\subsection{The sanctuary}

The dedications, explicitly offered in accordance with a vow (voto), provide detailed information concerning the presence of at least one templum/aedes and (probably several) lacus ("basins") 34 where sacrifices were performed.

As suggested by Antonio Rodríguez Colmenero, the lacus and laciculi of the sanctuary seem to have been used for different purposes: some of them (those incorporated into the temples) could serve as repositories for offerings or paraphernalia; others might have been small pools for ritual baths; others (with a rounded bottom) might have been intended for collecting water or blood; others again might have been for incinerating (parts of) victims (Rodríguez Colmenero 1999, 118-124). The texts explicitly refer to animals (hostiae) being consecrated (sacravit) by immolating them (immolantur), ${ }^{35}$ burning (cremantur) their internal organs (exta) in square basins (intra quadrata), and pouring (superfunditur) their blood (sanguis) ${ }^{36}$ over smaller basins (laciculis). ${ }^{37}$

The technical terms employed in the inscriptions are very specific and sophisticated. The least unusual is of course immolantur, i.e. the solemn act of sprinkling the victims' forehead with mola salsa (a mixture of toasted spelt and salt) and pouring on it some wine, and of course, by extension, the act of consecrating the animals (Prescendi 2007, 25, 36-37 and 102-110).

Once the victims had been killed and their entrails consulted, the latter were burnt (cremantur) not on the altar itself (as was the common practice) but apparently in square cavities cut into the granite (quadrata) (Prescendi 2007, 41-48). Cremare is a term frequently employed in Latin inscriptions and literary sources but almost always in the context of funerary epigraphy. As for animal sacrifices, apart from a few literary sources, ${ }^{38}$ the only epigraphic evidence known to me refers to the burning of a heifer in ara taurobolica duodena at Beneventum, in honor of Attis and Minerva Berecintia, iussu Matris Deum. ${ }^{39}$ This is not enough to

34 Other readings of the inscription no. 2: L. 1-3 [ded(icavit) lacum] Rodríguez Colmenero 1993, 70; [hic cum lacu sacravit] Rodríguez Colmenero 1997, 116; [cum lacu sacravit] Rodríguez Colmenero 1999, 84; in hoc / templo Lambrino 1954, 111; Búa Carballo 1999, 310. L. 4 DEM Lambrino 1954, 111.

35 immantur Contador de Argote 1732, 344; Hübner (CIL); inmolantur Rodríguez Colmenero 1997, 179.

36 santus Contador de Argote 1732, 344; Hübner (CIL).

37 L AC ICVIIS Contador de Argote 1732, 344; LAC KVII Hübner (CIL); PACIO Contador de Argote 1732, 344; Hübner (CIL).

38 Ovid., Fast. IV 639; Serv., Ad Aen. XI 197, 6; Tac., Hist. II 95.

39 CIL IX 1538: Attini sacrum / et Minervae Berecint(iae) / Concordia col(oniae) lib(erta) Ianuari [a] / c[y]mbal(istria) [l]oco secundo ob / criobolium factum M(atris) de(um) / Ma(gnae) tradentib(us) 
support the hypothesis of Scarlat Lambrino, who suggested that the subsequent formula (sanguis superfunditur) implies a taurobolium or criobolium and, thus, the involvement of Attis and Mater Deum (Lambrino 1954, 123-125). Superfundere sanguinem has no parallel either in Latin epigraphy ${ }^{40}$ or literature, although we do occasionally find fundere or profundere sanguinem used with reference to animal sacrifices or blood-libations. ${ }^{41}$ The term superfundere is found most often (in relation to water, oil, and other liquids) in the fields of medicine and cooking. ${ }^{42}$ A possible explanation is that the blood of the victims was cooked in order to prepare the sangunculus, a sort of fricassée to be consumed during the banquet at the end of the ceremony (cf. Prescendi 2007, 46-47). The term miscetur (inscription no. 5) is usually understood as the act of mixing something (i.e. libations or victims' blood and entrails linked to the effusio sanguinis), presumably in a lacus, but I would not exclude the possibility that the verb refers here either to the "joining" of the lacus to the temple (as suggested in the translation) or to the "sharing" by the devotees of these facilities, ${ }^{43}$ that is "taking part", "joining" the ceremony in honor of the gods (diis) who were thought to gravitate around the temple and the basin.

\subsection{The donor}

Although it is attested in all four surviving texts, ${ }^{44}$ the name of the donor, G. C. Calp. Rufinus, is not free of interpreative difficulties. Following Contador de Argote, it has been most frequently been read as G(naeus) C(aius) Calp(urnius)

Septimio / Primitivo augure et sac(erdote) / Servilia Varia et Terentia / Elisviana sacerd(ote) XVvir (ali) / praeeunte Mamio Secundo / haec iussu Matris deum / in ara taurobolica duo/dena cum vitula crem(ata) / sub die V Idus Aprilis / Modesto II et Probo co(n)s(ulibus).

40 A similar formula is mentioned in a Christian inscription (IHC 230) from Coelobriga (Celanova, $100 \mathrm{~km}$ north of Panóias), which reads: Funditur hic sanguis quo virus pellitur anguis.

41 See e.g. Cic., De divin. I 46; Appendix Vergiliana, Priapea 2.12-15; Petron., Sat. 97.9.

42 See the several occurrences in, for example, Apicius' De Re Coquinaria, Columella's De Re Rustica, Philumenus medicus' De Medicina, and Scribonius Largus' Compositiones.

43 Other readings: L. 1 cum hoc Russell Cortez 1947, 63; Lambrino 1954, 110; Alföldy 1997, 197; Alvar 2012, 144; cum aede(m) Santos, Pires and Sousa 2014, 219. L. 2 hic Contador de Argote 1732, 344; Búa Carballo 1999, 311; hyc Hübner (CIL); (h)uc Lambrino 1954, 110; VO Russell Cortez 1947, 63; et lacu, m(eatum) qui Rodríguez Colmenero 1997, 181; 1999, 90; et la/cu m(actatio)? ovi Rodríguez Colmenero 1993, 69. L. 3 TO O Russell Cortez 1947, 63; voto miscetur (sacravit) Rodríguez Colmenero 1997, 181; 1999, 91-92.

44 Apparently the donor did not sign the lost inscription. 
Rufinus but numerous alternatives have been hazarded: G(naeus) C(aecilius) Calp(urnius) Rufinus, G(naeus) C(assius) Calp(urnius) Rufinus, G(naeus) C(ai filius) Calp(urnius) Rufinus, G(aius) C(aristianus) Calp(urnianus) Rufinus, G(aius) C(ai filius) Calp(urnius) Rufinus. ${ }^{45}$ Several scholars, following Rodrigues de Aguiar, have preferred (as I do) to leave the name open: G(aius) C(?) Calp(urnius) Rufinus. ${ }^{46}$

At all events, Rufinus was a person of senatorial rank, since he can boast the title of $v$ (ir) $c$ (larissimus), ${ }^{47}$ which also allows us (in the absence of more precise palaeographic criteria) to place the dedications somewhere between the late 2nd and the mid-3rd century $\mathrm{CE}^{48}$ Géza Alföldy has offered the intriguing suggestion that the donor should be identified as a legatus iuridicus (Alföldy 1969, 110) or a provincial government official (Alföldy 1997, 237), while Rodríguez Colmenero prefers the hypothesis of a censitor sent by the Emperor or even a legatus Augusti pro praetore (Rodríguez Colmenero 1999, 127). ${ }^{49}$

Alföldy also suggests that Rufinus may have originated in Pamphylia, the only place (together with Antiochia ad Pisidiam) in which we find fairly extensive evidence both for the Calpurnii Rufini and the Isiac cults (Alföldy 1997, 240). Such an origin (say in Attaleia or Perge) would account for the use of Doric

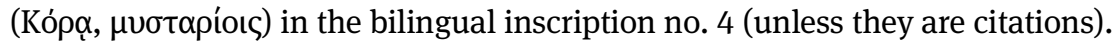

A somewhat different scenario may also be suggested, which takes account of the proximity of the gold-mines. On this view, the senator may have lived in Lusitania and had business with the gold mines of the region (Tranoy 2004, 90). The mention in a funerary inscription from Ebora (Evora) of a certain Calpurni(a) Titi filia Rufiniana seems to suggest the presence of the family of the Calpurnii Rufini in southern Portugal at least (IRCPacen 391).

45 Búa Carballo 1999; Rodríguez Colmenero 1997; 1999; Redentor 2016, 214-217. The cohabitation, within the same inscription, of $G$ and $C$ (the difference between which looks substantial only in the inscription $n^{\circ}$ ) for the name Gaius has several parallels, which include also the formula Gaius Cai filius, but never without the mention of the $F$ of the patronymic and never with the patronymic itself placed before the nomen gentilicium.

46 Alföldy 1997; Alvar 2012; Santos, Pires and Sousa 2014.

47 The abbreviation is interpreted as $v$ (oti) c(ompos) by Vasconcellos 1897-1913, III; Russell Cortez 1947, 57; Lambrino 1954, 109-110; García y Bellido 1956, 42; 1967, 133; as v(ir) c(onsularis) by Contador de Argote 1732, I, 345-346; Hübner (CIL).

48 End of the 2nd - beginning of the 3rd century CE: RICIS, Tranoy 2004, 89; beginning of the 3rd century CE: Lambrino 1954, 123. The chronology is anticipated to 75-200 CE by Russell Cortez 1947, 28.

49 We can certainly do without the recent hypothesis by María Paz De Hoz, who identifies in this senator a sort of missionary traveling with the purpose of proselytizing in favor of his own personal religion (De Hoz 2011, 82). 


\section{Contextualization}

The site of Panóias offers the rare possibility of identifying a sort of archaeological "rock stratigraphy". The analysis of the material clearly shows a sequence of at least three different phases of development: first, the network of "cupules" connected by channels, then the square or rectangular cisterns covered and/or protected by metallic grids, some of which were later incorporated into the three (or more) buildings whose walls were fitted to the rock-surfaces (Lambrino 1954, 127-128). It is not impossible that three incisions in the shape of crosses, identified by Rodríguez Colmenero $(1999,73)$ not far from a rock, may even attest to a fourth, Christian, phase.

Although it seems reasonable enough to associate the third stage with Rufinus' inscriptions (text 2 explicitly mentions a temple), the chronology of the earlier, presumably pre-Roman, phases remains uncertain. Nearly half a century ago, László Castiglione pointed out that

the different cuttings on the rock are not of the same age. The earliest grooves, round cav-
ities connected by canals, circular and quadrangular but irregular basins, outlets leading
to the sides of the rocks, agree with the grooves of the prehistoric sacrificial rocks well
known from France (...). On certain rocks these were effaced, and on others completely
removed by the regularly circular and quadrangular basins made with a more developed
stone cutting technique, the partial levelling of the surface of the rocks and the paths
leading up and the steps.
(Castiglione 1970, 101)

“Cupules" are known already from the Palaeolithic period but become very common only during the Neolithic and Bronze Ages (Couderc 2016, 15). In Europe, they are concentrated in three famous megalithic areas: Ireland, Brittany, and north-western Iberia. ${ }^{50}$ In the latter area, they begin in the fourth millennium BCE (in the area of Frieiro in Trás-os-Montes, 32 "cupules" of this date are known, associated with Neolithic amulets and scrapers, and probably linked with mortuary incineration: see already Vasconcellos 1897-1913, I, 358-359), but increase in number during the Bronze Age. During this period, the "cupules" are often accompanied by incisions in the shape of crosses (which perhaps raises doubts about a "Christian" fourth phase at Panóias) and by the so-called "pierres aux pieds” (Couderc 2016, 224-231), i.e. human or animal footprints carved into the rock. Similar so-called "petrosomatoglyphs" have been identified at Panóias too. Both Contador de Argote and Kingston noted the vestiges of three human footprints carved on the surface of a rock. ${ }^{51}$ A pair of footprints (left and right) was

50 Couderc 2016, 151-157 and 201-204 (201-203 on Panóias).

51 Contador de Argote 1732, I, 347; Kingston 1845, II, 350; Lambrino 1954, 125. 
found beside a channel leading from a square basin, facing south, while a third (right) footprint is located crosswise in front of them, facing east (Rodríguez Colmenero 1999, 115). Rodríguez Colmenero has found traces of two further footprints, one facing the other (Rodríguez Colmenero 1999, 58). But it is likely that many others were originally carved in the area: Kingston records that "[s]hallow steps were carved all round". ${ }^{52}$

These footprints have generally been interpreted as Roman. Alföldy thought they marked the base of a bronze statue (Alföldy 1997, 215, n. 99); Lambrino preferred to link them to the so-called "Serapis feet", or similar healing votives, or even with vestigia left pro itu et reditu by pilgrims under the protection of Caelestis; ${ }^{53}$ Jaime Alvar understands the pair of prints as symbols of Serapis standing over the Nile (represented by the channel in-between), while the isolated footprint would indicate the place where the priest or the devotee had to kneel piously in front of the god (Alvar 2012, 145-146, $\mathrm{n}^{\circ}$ 198). Rodríguez Colmenero has even toyed with the suggestion that the (absolutely unproved) existence of a $27 \mathrm{~m}$ long tunnel connecting the rock with the footprints and Rock I (with the four surviving inscriptions) may have been a complex for a mysterycult, with the initiate's passage through the tunnel hinting at his symbolic death (Rodríguez Colmenero 1999, 117).

Castiglione, however, demurred, pointing out that there are better parallels in Celtic sacrificial sites all over western and northern Europe from the Neolithic up to the Iron Age (Castiglione 1970, 100-102). There are numerous examples in the Iberian peninsula itself (Vasconcellos 1897-1913, I, 381-383; Couderc 2016, 229), notably in Galicia: the indigenous rock sanctuaries of S. Salvador do Mundo (south of the Douro), Fraga das Pasadas (Soutelo), Bustelo (Chaves), and Peña de Santa Maria (Iruelos del Mesón Nuevo) are all not far from Panóias. ${ }^{54}$ There are also close parallels in France: the "pierre Le Mulot" of Bleurville (Vosges), for example, has three very similar footprints; both the Neolithic sites of the "pieds de Sainte-Anne" and "de la Vierge" at Nanteau-sur-Essonne (Seine-et-Marne) contain two similar footprints at right-angles to one another, pointing south and east, exactly as at Panóias (Baudouin 1914).

52 Kingston 1845, II, 350 (my italics). Cf. Lambrino 1954, 125. For "step” meaning "the mark or impression made by the foot on the ground; a footprint", see OED sense 9; the earliest citation is dated c. 1290.

53 Lambrino 1954, 125-126. On the "Serapis feet" see Puccio 2010, 139-143 (esp. 142-143 specifically in relation to the Iberian peninsula). On the dedication of Isiac vestigia, see Gasparini (forthcoming), with a discussion including the material found in Spain.

54 Rodríguez Colmenero 1999, 106 n. 7; Santos 2010c, 154 and 169, figs. 21-22. 
Castiglione's argument is compelling. If, then, the "cupules" and the footprints of Panóias belong to a common pre- or proto-historical horizon (whether of Neolithic or Bronze-Age date), and if Rufinus was responsible for the construction of the temple(s) some time between the late Antonine dynasty and the mid-3rd century CE, it is very difficult to date the intermediate phase, mainly characterized by the excavation of staircases and small cisterns. Nearly 150 (both pre-Roman and Roman) sites in the Iberian peninsula have been interpreted as rock sanctuaries (most of them concentrated in northern Portugal, Galicia, and Castile and León: see Rodríguez Colmenero 2000; Salinas de Frías 2001). Rock staircases, ${ }^{55}$ Latin inscriptions, ${ }^{56}$ and individual or clustered cisterns or tanks, some of which have indications of covers or metallic grids and are sometimes explicitly called lacus, laciculi, and quadrata, are all common features of these sanctuaries, especially in the region of the Douro valley and Trás-os-Montes. ${ }^{57}$ Just in the roughly square area between Ourense (to the north), Guarda (south), Braganca (east) and the Atlantic (west), as many as 48 rock inscriptions have been identified, 20 of them with explicitly religious content (Rodríguez Colmenero 1993 and 1995).

The case of Pena Escrita (Vilar de Perdizes, Montalegre) is particularly interesting in this context (Santos 2010a, 184-187; 2010b, 129-136). In this sanctuary, a rock-cut staircase led up to an altar, with a square basin and channels nearby, and dedications to Jupiter and Laraucus. See also the inscription signed by Silius Eorinus at Oia (Oya), which mentions a lacu\{u\}s hostiarum, i.e. a cistern for use during or after the sacrificial ritual. ${ }^{58}$ These architectural facilities attest to a local sacrificial practice, and specifically the suovetaurilia (Alföldy 1997, 198-209), details of which are provided by Strabo, who also records the local preference of the Lusitanians for hecatombs, ${ }^{59}$ and by several reliefs and

55 For example, at Vila Real, Castro das Cruvas (Murça), Outeiro dos Mouros (Castelões), São Salvator do Mundo (São João da Pesqueira), Santa Marina das Aguas Santas (Cameixa, Boboras), Pias dos Mouros (Argeriz, Valpaços). Cf. Santos 2010a, 193-195; 2010b, 149-151.

56 For example, at São Martinho de Mouros (Mogueira, Resende, Viseu), Pena Escrita (Vilar de Perdizes), Pias dos Mouros (Argeriz, Valpaços), Mougas (Oia). Cf. Maciel 2007; Santos 2010a, 187-195; 2010b, 137-151.

57 For example, at Santa Marina das Aguas Santas (Cameixa, Boboras), Fundões (Alijó), Penedo Linhares (Alvão), Campa dos Mouros (Monte Fralães). Cf. Rodríguez Colmenero 2000; Tranoy 2004, 88-89.

58 HEp 1995, 660: Sili Eorini hos(tiarum) / lacuus. Cf. Rodríguez Colmenero 1993, 74-77, nº 38; Tranoy 2004, 88-89.

59 Strabo, III 3, 6-7: "The Lusitanians are given to offering sacrifices, and they inspect the vitals, without cutting them out. Besides, they also inspect the veins on the side of the victim; and they divine by the tokens of touch, too (...). They eat goat's meat mostly, and to Ares they sacrifice a he-goat and also the prisoners and horses; and they also offer hecatombs of each 
inscriptions (Maciel 2007), including the well known example from Cabeço de Fráguas (Pousafoles, Sabuga). ${ }^{60}$

Epigraphic and archaeological evidence confirms the continuity of these sacrificial practices between the pre-Roman and Roman periods, and the involvement in the Imperial period of (both human and divine) agents of different cultural origins. The rock sanctuary of Herdade da Lentisca (Santa Eulália, Elvas) included a tank with bevelled edges (designed for the insertion of a cover and/or of a metallic grid) and an altar dedicated to Bellona (beginning of the 1st century CE) by a local man named Valgius (Maciel 2007, 34 n. 30). The presence of Isis and Serapis at Panóias (Pannonias) has been linked with the presence in the region of Legio VII Gemina (created by Galba in 68 CE, active mainly in Pannonia, and finally moved to Léon, $225 \mathrm{~km}$ north-east of Panóias). ${ }^{61}$ However, it is probably better to follow Alföldy in linking the toponym Pannonias with the Celtic root *pan or *pen, i.e. "water", "humidity". ${ }^{6}$

\section{Micro-strategies of memorialization}

Placing Panóias within the archaeological and epigraphic context of the Iberian peninsula makes it clear that, so far from being something exceptional, Rufinus' integration of Roman deities within a pre-Roman rock sanctuary that was equipped with facilities specifically focusing on the sacrificial act belongs to a standard pattern of Roman (re-)sacralization. What is exceptional at Panóias is the unusually rich archaeological and epigraphic evidence, which provides an insight into the micro-strategies employed to negotiate between an existing cultic site and Rufinus' desire to memorialize his own individual

\footnotetext{
kind, after the Greek fashion - as Pindar himself says, 'to sacrifice a hundred of every kind'” (transl. H. L. Jones). Cf. Rodríguez Colmenero 1999, 130-135; Santos 2007 and 2008.

60 The text runs: Oilam Trebopala indi porcom Laebo, comaiam Iccona Loiminna, oilam usseam Trebarune indi taurom ifadem Reue Tre. See Rodríguez Colmenero 1993, 104-105, n 47; Maciel 2007, 34-35; Schattner and Santos 2010.

61 Russell Cortez 1947, 9-24, 28, 32-34. Cf. Rodríguez Colmenero 1999, 19 n. 1.

62 Alföldy 1997, 176 n. 2. Cf. Rodríguez Colmenero 1999, 19 n. 1 (and n. 2 with a third, equally unlikely hypothesis of etymology from pannus). On the basis of RICIS 603/0801, it has been claimed that the Isiac deities were worshipped in a rock sanctuary at the site of Montroig del Camp (Baix Camp, Tarragona), where basins, altars, staircases, and channels have been found: cf. Rodriguez Colmenero 1999, 136. But Gorostidi Pi 2010, 124, no 96 convincingly suggests that this is a funerary inscription of the 16th-17th century mentioning the name Isidro.
} 
efforts of appropriation, sacralization, and redefinition. Whatever the donor's origins and period of presence in the area, Rufinus seems to have been aware of the danger of causing local resentment by his re-modelling of the site. The repeated invocation of dii (deaeque omnes) and specific local deities such as the numina Lapitearum implies a conscious desire to avoid conflict with preexisting religious traditions even as he introduced new divinities to the site. Rufinus made an effort to evoke and acknowledge local sensibilities and traditions, implying a desire to engage with local actors.

This is not an isolated case. At Asturica Augusta (Astorga, $200 \mathrm{~km}$ northeast of Panóias), C. Iulius Silvanus Melanio, procurator Augustorum provinciae Hispaniae Citerioris during the years 198-209 CE, made a dedication to Serapis, Isis, Korê invicta, Apollo Grannus, and Mars Sagatus. ${ }^{63}$ This inscription contains the sole explicit mention of Korê together with the Isiac deities other than in Rufinus' text 2. The same official made two further dedications at Astorga, one to the Capitoline triad and all the other immortal gods ${ }^{64}$ and the other, in Greek, to the two Nemeseis of Smyrna. ${ }^{65}$ All three inscriptions illustrate Silvanus' cumulative (and non-exclusive) religious preferences. Especially notable is the choice of Greek as a more effective code when communicating with Greek gods rather than with the local audience.

Rufinus and Silvanus Melanio were not the only members of the administrative elite who dedicated to the Isiac gods in this area at the end of the 2nd to the beginning of the 3rd century CE. Just after Silvanus, another equestrian procurator, Claudius Zenobius (212-222 CE), set up an altar Invicto Deo Serapidi et Isidi beside that of Silvanus at Astorga. ${ }^{66}$ At Legio VII (León, c. 200 CE), two others, L. Cassius Paulinus Augustanius Alpinus Bellicius Sollers, probably the son of P. Cassius Dexter (cos. suff.? $151 \mathrm{CE}$ ) and no doubt currently legate of leg. VII

63 AE 1968, 230 = RICIS 603/1101: Serapidi / sancto / Isidi mironymo / Core invictae / Apollini / Granno / Marti Sagato / Iul(ius) Melanio / proc(urator) / Augg(ustorum) / v(otum) s(olvit). Cf. Mangas 1996, 48, nº b; Alvar 2012, 131-132, nº 184.

64 AE 1968, 231: I(ovi) O(ptimo) M(aximo) / Custodi / Iunoni Reginae / Minervae Sanctae / ceterisque Dis / Deabusque / immortalibus / Iulius Siluanus / Melanio proc(urator) Aug(ustorum duorum) / provinc(iae) Hisp(aniae) Cit(erioris) / dicavit. Cf. Mangas 1996, 48, nº a; Alvar 2012, 132 n. 102.

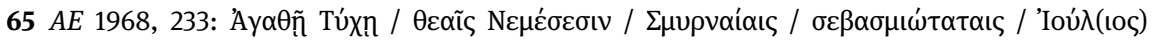

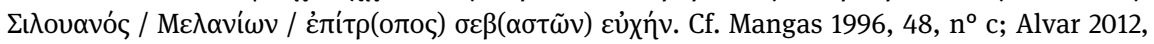
132 n. 103. On the two Nemeseis of Smyrna, whose mother was Night, see Paus. VII 5, 2-3; cf. Karanastassi 1992.

66 AE 1968, 232 = RICIS 603/1102: Invicto Deo / Serapidi et / Isidi / Cl(audius) Zenobius / proc(urator) $<A u=X X>g\left(\right.$ usti). Cf. Alvar 2012, 131, $\mathrm{n}^{\circ} 183$, with bibliography. 
Gemina, alongside his equally polyonymous son, honored four healing deities, Aesculapius, Salus, Serapis and Isis. ${ }^{67}$

Whereas in text 3 Rufinus invoked all the local deities, the unique invocation of Serapis as hypsistos ("the Highest") in the bilingual text $4^{68}$ seems to have the specific function of representing his religious act as part of a lengthy continuum of practice at this site and yet at the same time establishing a privileged, intimate communication with Serapis. ${ }^{69}$ By elevating Serapis over all the other gods, Rufinus asserts his justification for intervening into the local religious tradition and defends his substantial economic investment. It is certainly likely to claim that the switch to Greek in text 4 (parallel to Silvanus' use of Greek in his dedication to the Nemeseis of Smyrna) suggests a desire to establish a more intimate channel of communication with a god perceived in that moment as Greek (cf. De Hoz 2011, 81-82). Moreover, the use of Greek, in an area where it was of course virtually unknown (and indecipherable), in a text

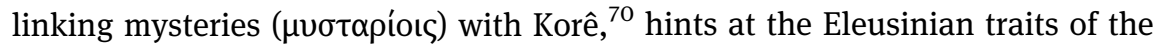
ceremonies performed in Rufinus' re-modelled Panóias (Rodríguez Colmenero 1999, 112-113). The thematic parallel perceived between Demeter's search for her daughter Korê and Isis' search for her husband (Osiris/Serapis) at the Inventio Osiridis had led, already at the beginning of the 3rd century CE, to the notion that Isis was looking for her son Harpocrates. ${ }^{71}$

Choosing the most telling location for his intervention was also a crucial factor. Unlike his peers in Astorga or León, Rufinus decided to build his shrine far away from an urban center where selective monumentalization would enjoy high visibility. Instead he chose a remote, albeit locally-famous and numinous, spot for his investment, a set of granite rocks with a naturally attractive force which could get, very early, vocation to be sacralized (Tranoy 2004, 87).

Summing up, we have little idea of how the sanctuary might have appeared prior to Rufinus' intervention but there can be no doubt that his new constructions

67 AE 1967, 223 = 1968, 235 = RICIS 603/1001: (A)esculapio / Saluti / Serapi(di) Isidi / L(ucius) Cassius Paullus / Augustanius Alpinus / Bellicius Sollers / et M(arcus) Cassius Agrippa / Sanct(i)us Paullinus / Augustanius Alp(i)nu[s]. Cf. Alföldy 1999, 330, nos. 3 and 4; Alvar 2012, 130, nº 182, with bibliography (wrongly claiming that Agrippa was a procurator).

68 Heitsch 1961, IL, followed by Bricault and Dionysopoulou 2016, 116, claims that the same epithet is used of Serapis (again in the 3rd century CE) in P.Schubart 12, 2, but the epithet

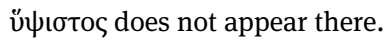

69 Belayche 2005a (2011), 146 and 2005b, 433 and 439-440.

70 Persephone was locally identified with the Lusitanian goddess Ataecina or Ataegina. See Vasconcellos 1897-1913, II, 146-173; Abascal Palazón 2002.

71 Min. Felix, Octav. XXI; Lact., Inst. Div. I 17.6 and 21.20; cf. Epit. 18.5; Arnob., Adv. nationes I 36.6 . 
and installations radically altered it. The open-air site was "domesticated" and partially converted into an elegant Roman sanctuary. Classical columns rose up from the primordial natural granite. ${ }^{72}$ The small temples, profusely adorned with capitals and polished pediments but perched near the top of the rocks, were intentionally isolated and hard to reach (especially the northern temple, which was accessible only by means of a steep, narrow flight of steps and a very narrow ledge). The altars were placed on the granite outcrops nearby. It must have been an extremely arduous process to transport the victims up there alive.

It is impossible on the basis of the available material to decide whether these three small buildings, scattered over the rocks and almost inaccessible, were intended to constitute a topographic and cultic "unity", and whether they might have formed stationes in, say, processions. What is likely is that Rufinus' sanctuary provided an arena for negotiating multiple narratives, in particular those represented by his individual efforts at memorialization and the immemorial local religious history. Memorialization is a long-term process and the media (including architecture) that do not pay attention to it risk becoming irrelevant over time. This means that both sequencing and moment must be carefully selected, and the media chosen so as to ensure their intelligibility into the future. This can be done either by explicitly affirming such perpetuity (e.g. lacus aeternus in text 3) or by creating a context capable of shaping the behavior of future visitors to the sanctuary. At Panóias, sacrifice had probably always played a central role in local cultic praxis. Rufinus attempted to regulate this tradition by providing explicit and rather detailed instructions about the procedures to be followed (text 1).

The case-study of Panóias witnesses the spontaneity and randomness with which individuals could unsystematically implement the Isiac cults, even far from the preconfigured behaviors and the institutional pressure of what we call "civic religion". Panóias shows how a pre-Roman rock sanctuary could, during the period between the late 2nd and mid-3rd centuries CE, be experienced as a Serapeum and adapted to specific mysteric requirements. Moreover, it highlights the strategies used by the senator Rufinus to reckon with a highly-charged past, inserting his religious innovation into a historical continuum in an appropriate and respectful manner, thus prolonging and renewing a salient ancestral activity.

72 See Rodrigues de Aguiar’s Relação apud Rodríguez Colmenero 1999, 19: “basas e capiteis e pedaços de colunas, redondas e pedras de frisos, entabolamentos, caleiros e outras muitas, $e$ muito diversas e algús pedaços de colúnas e pedras de jaspe, e outra muito branca a modo de pedra de sal, e outra de grâ miuda como pedra de açucar". 
In conclusion, this is an excellent example of the possible micro-mechanisms of appropriation through which, in antiquity, religious entrepreneurs could negotiate their innovations, find spaces for creativity and individual distinction, and therefore empower and enlarge their agency.

\section{Bibliography}

Abascal Palazón, Juan Manuel 2002. 'Ataecina'. In Ribeiro 2002, 53-60.

Abreu, Mila Simões de 2016. 'Alcune note su Panóias, un santuario rupestre nel Douro', Santuários 6. 13-24.

Alföldy, Géza 1969. Fasti Hispanienses. Senatorische Reichsbeamte und Offiziere in den spanischen Provinzen des römischen Reiches von Augustus bis Diokletian. Wiesbaden.

Alföldy, Géza 1995. 'Inscripciones, sacrificios y misterios. El santuario rupestre de Panóias/ Portugal. Informe preliminar', Mitteilungen des Deutschen Archäologischen Instituts. Abteilung Madrid 36. 252-258.

Alföldy, Géza 1997. 'Die Mysterien von Panóias (Vila Real, Portugal)', Mitteilungen des Deutschen Archäologischen Instituts. Abteilung Madrid 38. 176-246.

Alföldy, Géza 1999. Städte, Eliten und Gesellschaft in der Gallia Cisalpina: Epigraphischhistorische Untersuchungen. HABES 30. Stuttgart.

Alföldy, Géza 2002. 'Panóias. 0 santuário rupestre'. In Ribeiro 2002, 211-214.

Alvar, Jaime 2012. Los cultos egipcios en Hispania. Besançon.

Azevedo, António Manuel Caldeira 1998. Do significado religioso de Panóias. Chaves.

Bárcia, Paula 1982. As 'Religiões da Lusitânia' de J. Leite de Vasconcelos. Contribuiçao para o seu estudo. Alguns comentarios e índices gerais. Lisboa.

Baudouin, Marcel 1914. 'Les pieds humains sculptés de la Pierre Le Mulot $\left(\mathrm{N}^{\circ} 1\right)$, à Bleurville (Vosges)', Bulletins et Mémoires de la Société d'Anthropologie de Paris 5.3. 181-196.

Belayche, Nicole 2005a. 'Hypsistos. Une voie de l'exaltation des dieux dans le polythéisme gréco-romain', Archiv für Religionsgeschichte 7. 34-55 [Eng. transl. 'Hypstistos. A Way of Exalting the Gods in Graeco-Roman Polytheism.' In The Religious History of the Roman Empire: Pagans, Jews, and Christians, ed. John A. North, Simon R.F. Price. Oxford Readings in Classical Studies. Oxford. 139-174].

Belayche, Nicole 2005b. 'De la polysémie des épiclèses. Hypsistos dans le monde grécoromain.' In Nommer les dieux. Théonymes, épithètes, épiclèses dans l'Antiquité, ed. Nicole Belayche et al. Recherches sur les rhétoriques religieuses 5. Turnhout. 427-442.

Blázquez Martínez, José María 1962. Religiones primitivas de Hispania, I. Fuentes literarias y epigráficas. Roma.

Bricault, Laurent (ed.) 2008. Bibliotheca isiaca, I. Bordeaux.

Bricault, Laurent; Dionysopoulou, Efstathia 2016. Myrionymi 2016. Épithètes et épiclèses grecques et latines de la tétrade isiaque. Toulouse.

Búa Carballo, Carlos 1999. 'Hipótesis para algunas inscripciones rupestres del occidente peninsular.' In Pueblos, lenguas y escrituras en la Hispania prerromana. Actas del VII Coloquio sobre Lenguas y Culturas Paleohispánicas (Zaragoza, 12-15 marzo 1997), ed. Francisco Villar Liébana, Francisco Beltrán Lloris. Salamanca. 309-327.

Cardoso, Mário 1943. Algunas inscripções Lusitano-Romanas da Regiâo de Chaves. Chaves. 
Castiglione, László 1970. 'Vestigia', Acta Arch. Acad. Scient. Hungaricae 22. 95-132.

Contador de Argote, Jeronymo 1732. Memórias para a História Ecclesiástica do Arcebispado de Braga, I-IV. Lisboa.

Couderc, Jean-Mary 2016. Géographie et archéologie des cupules. Diss. Université de Tours.

De Hoz, María Paz 1997. 'Epigrafía griega en Hispania', Epigraphica 59. 29-96.

De Hoz, María Paz 2011. 'Bilingüismo grecolatino en la península Ibérica. Testimonios de code-switching.' In A Greek Man in the Iberian Street. Papers in Linguistics and Epigraphy in Honour of Javier de Hoz, ed. Eugenio R. Luján, Juan Luis García Alonso. Innsbruck. 79-91.

De Hoz, María Paz 2013. 'Cultos griegos, cultos sincréticos y la inmigración griega y grecooriental en la peninsula Ibérica.' In El Oriente griego en la península Ibérica. Epigrafía e historia, ed. María Paz De Hoz, Gloria Mora. Bibliotheca Archaeologica Hispana 39. Madrid. 205-254.

De Hoz, María Paz 2014. Inscripciones griegas de España y Portugal (IGEP). Bibliotheca Archaeologica Hispana 40. Madrid.

Dias, Maria Manuela Alves; Gaspar, Catarina I. S.; Mota, Bernardo M. 2001. Inscrições gregas. Lisboa.

Domergue, Claude 1990. Les mines de la péninsule Ibérique dans l'Antiquité romaine. Rome.

Fonseca Sorribas, Diana 2012. 'El municipium romano de Aquae Flaviae y su problemática', Antesteria 1. 519-528.

Freitas, Isabel; Mesquita, Herculano; Pádua, Fernando; Sousa, Orlando 2012-2013. 'Panóias. De fragas a santuário. 0 que mostrar? E a quem?', Arqueologia \& História 64-65. 183-189.

Garcia, José Manuel 1991. Religiões antigas de Portugal: aditamentos e observações às 'Religiões da Lusitânia' de J. Leite de Vasconcelos. Fontes epigráficas. Lisboa.

García y Bellido, Antonio 1956. El culto a Sárapis en la península ibérica. Madrid.

García y Bellido, Antonio 1967. Les religions orientales dans l'Espagne romaine. Études Préliminaires aux Religions Orientales dans l'Empire Romain 5. Leiden.

Gasparini, Valentino (forthcoming). 'Isis' Footprints. The Petrosomatoglyphs as Spacial Indicators of Human-Divine Encounters'.

Gil Fernández, Juan 1985. 'Notas sobre el Lusitano'. In Actas del III Colóquio sobre Lenguas y Culturas Paleohispánicas (Lisboa, 5-8 noviembre 1980), ed. Jesús Javier De Hoz Bravo. Salamanca. 365-370.

Gorostidi Pi, Diana 2010. Ager Tarraconensis, 3. Les inscripcions romanes (IRAT). Tarragona.

Guerra, Amílcar 2002. 'Omnibus Numinibus et Lapitearum. Algumas reflexões sobre a nomenclatura teonímica do Ocidente peninsular', Revista Portuguesa de Arqueologia 5. 147-159.

Heitsch, Ernst 1961. Die griechischen Dichterfragmente der römischen Kaiserzeit. Göttingen. Herculano, Alexandre 1839a. 'A antiga cidade de Panonias', O Panorama 3 (106). 149-150.

Herculano, Alexandre 1839b. 'Panoias II', O Panorama 3 (107). 156-157.

Karanastassi, Paulina 1992. S.v. 'Nemesis', LIMC 6.1. 762-770.

Kingston, William H. G. 1845. Lusitanian Sketches of the Pen and Pencil, I-II. London.

Lambrino, Scarlat 1954. 'Les divinités orientales en Lusitanie et le sanctuaire de Panóias', Bulletin des Études Portugaises et de l'Institut Français au Portugal 17. 93-129.

Maciel, Manuel Justino 2007. 'Imagens de arquitecturas. Quadrata, lacus e laciculi nos santuários rupestres do período romano em Portugal', Revista do Instituto de História da Arte 3. 25-39. 
Mangas, Julio 1996. 'Cultos minorasiáticos en el noroeste de la Hispania romana'. In Homenaje al profesor Manuel Fernández-Miranda, ed. Teresa Chapa Brunet, María de los Angeles Querol Fernández. Complutum, Extra 6.1. Madrid. 483-490.

Martins, Carla Maria Braz (ed.) 2010. Mineração e povoamento na antiguidade no alto Trás-osMontes ocidental. Porto.

Pereira, Francisco Fernandes (alias Francisco dos Prazeres Maranhão) 1836. Breve notícia da terra de Panoias, cantão famigerado na antiguidade, do qual se formou a melhor parte da comarca de Vila Real. Coimbra [non vidi].

Pereira, Gabriel 1895. 'Os fragões de S. Pedro de Valle de Nogueiras', Boletim da Associação de Archeólogos Portugueses 7. 51-53 [non vidi].

Pires, Hugo et al. 2014. 'Morphological Residual Model. A Tool for Enhancing Epigraphic Readings of Highly Erosioned Surfaces'. In Information Technologies for Epigraphy and Cultural Heritage. Proceedings of the I EAGLE International Conference, ed. Silvia Orlandi, Raffaella Santucci, Vittore Cesarosa, Pietro Maria Liuzzo. Roma. 133-144.

Prescendi, Francesca 2007. Décrire et comprendre le sacrifice. Les réflexions des Romains sur leur propre religion à partir de la littérature antiquaire. Potsdamer Altertumswissenschaftliche Beiträge 19. Stuttgart 2007.

Puccio, Laetizia 2010. 'Pieds et empreintes de pieds dans les cultes isiaques. Pour une meilleure compréhension des documents hispaniques', Mélanges de la Casa de Velázquez 40.2. 137-155.

Redentor, Armando 2016. 'Da exibição de inscrições em santuários rupestres: os casos da Fonte do Ídolo e de Panóias'. In L'iscrizione esposta. Atti del Convegno Borghesi 2015, ed. Angela Donati. Epigrafia e Antichità 37. Faenza. 189-220.

Ribeiro, José Cardim (ed.) 2002. Religiões da Lusitânia. Loquuntur saxa. Lisboa.

Rodríguez Colmenero, Antonio 1993. Corpus-catálogo de inscripciones rupestres de época romana del cuadrante noroccidentale de la península ibérica. La Coruña.

Rodríguez Colmenero, Antonio 1995. 'Corpus de inscripciones rupestres de época romana del cuadrante NW de la Peninsula Iberica'. In Saxa scripta (inscripciones en roca). Actas del Simposio Internacional Ibero-Itálico sobre epigrafía rupestre, ed. Antonio Rodríguez Colmenero, Lidio Gasperini. La Coruña. 117-258.

Rodríguez Colmenero, Antonio 1997. Aquae Flaviae. I: Fontes epigráficas da Gallaecia meridional interior. Chaves ( $2^{\circ}$ ed., Chaves 1987).

Rodríguez Colmenero, Antonio 1999. O Santuário rupestre galaico-romano de Panóias (Vila Real, Portugal). Novas achegas para a sua reinterpretaçâo global. Lisboa.

Rodríguez Colmenero, Antonio 2000. “'Deorum Temene”. Espacio sagrado y santuarios rupestres en la Gallaecia romana. Un intento de clasificación'. In Actas do III Congreso de Arqueología Peninsular, VI, ed. Trinidad Nogales Basarrate. Porto. 153-195.

Russell Cortez, Fernando 1947. Panóias, cividade dos Lapiteas. Subsídios para o estudo dos cultos orientais e da vida provincial romana na região do Douro. Porto.

Salinas de Frías, Manuel 2001. 'La religiosidad de las poblaciones antiguas de Salamanca y el Norte de Cáceres’, Palaeohispanica 1. 151-172.

Santos, Maria João Correia 2007. 'El sacrificio en el Occidente de la Hispania romana: para un nuevo análisis de los ritos de tradición indoeuropea', Palaeohispanica 7. 175-217.

Santos, Maria João Correia 2008. 'The Triple Animal Sacrifice and the Religious Practice of the Indigenous Western Hispania', Acme 103. 253-276.

Santos, Maria João Correia 2010a. 'Inscripciones rupestres y espacios sagrados del norte de Portugal: nuevos datos y contextualización. Los casos de Pena Escrita, Mogueira y Pias 
dos Mouros'. In Celtic Religion Across Space and Time, ed. Jesús Alberto Arenas Esteban. IV Workshop FERCAN. Toledo. 181-198.

Santos, Maria João Correia 2010b. 'Inscrições rupestres do Norte de Portugal: novos dados e problemática', Sylloge Epigraphica Barcinonensis 8. 123-152.

Santos, Maria João Correia 2010c. 'Santuários rupestres no Ocidente da Hispania indoeuropeia. Ensaio de tipologia e classificação', Palaeohispanica 10.147-172.

Santos, Maria João Correia; Pires, Hugo; Sousa, Orlando 2014. 'Nuevas lecturas de las inscripciones del santuario de Panóias (Vila Real, Portugal)', Sylloge Epigraphica Barcinonensis 12. 197-224.

Schattner, Thomas G. 2017. 'Projet d'étude des cultes et des sanctuaires de l'ouest de la péninsule ibérique à l'époque romaine. Réflexions sur les nouvelles fondations'. In Quand naissent les dieux. Fondation des sanctuaires antiques: motivations, agents, lieux, ed. Sandrine Agusta-Boularot, Sandrine Huber, William Van Andringa. Collection de l'École française de Rome 534. Rome. 351-381.

Schattner, Thomas G.; Correia Santos, Maria João (eds) 2010. Porcom, Oilam, Taurom. Cabeço das Fráguas: o santuário no seu contexto. Actas da jornada realizada no Museu da Guarda (23 Abril 2010). Iberografias 6. Guarda.

Sousa, Rogério; Ribeiro da Silva, João (eds) 2013. Serápis nos confins do Império: o complexo sagrado de Panóias. Vila Real.

Tranoy, Alain 2004. 'Panóias ou les rochers des dieux', Conimbriga 43. 85-97.

Vasconcellos, José Leite de 1895a. 'Museu Municipal em Villa-Real (Tras-os-Montes)', O Archeologo Português 1. 37-43.

Vasconcellos, José Leite de 1895b. 'Estação luso-romana de Panoias', O Archeologo Português 1. 271-272.

Vasconcellos, José Leite de 1897a. 'Estudos sobre Panoias. 1. Cavidades abertas em fragas; 2. Iscripção greco-romana', O Archeologo Português 3. 58-61.

Vasconcellos, José Leite de 1897b. 'Estudos sobre Panoias. 3. Restituição de uma iscripção perdida', O Archeologo Português 3. 177-180.

Vasconcellos, José Leite de 1897-1913. Religiões da Lusitania na parte que principalmente se refere a Portugal, I-III. Lisboa.

Wild, Robert A. 1984. 'The Known Isis-Sarapis Sanctuaries of the Roman Period', Aufstieg und Niedergang der römischen Welt II 17.4. Berlin. 1739-1851. 
